\title{
An Interactional Theory of International Legal Obligation
}

\author{
Jutta Brunnée and Stephen J. Toope
}

Version Post-print/accepted manuscript

Citation Brunnée, Jutta and Toope, Stephen J., An Interactional Theory of

(published version) International Legal Obligation (July 12, 2008). Jutta Brunnée and Stephen J. Toope, LEGITIMACY AND PERSUASION IN INTERNATIONAL LAW, Cambridge University Press, 2010. https://doi.org/10.1017/CBO9780511781261.003

Publisher's Statement This material has been published in Legitimacy and Persuasion in International Law by Jutta Brunnée and Stephen J. Toope. This version is free to view and download for personal use only. Not for redistribution, re-sale or use in derivative works. (C) Cambridge University Press 2018.

How to cite TSpace items

Always cite the published version, so the author(s) will receive recognition through services that track citation counts, e.g. Scopus. If you need to cite the page number of the author manuscript from TSpace because you cannot access the published version, then cite the TSpace version in addition to the published version using the permanent URI (handle) found on the record page.

This article was made openly accessible by $U$ of $T$ Faculty. Please tell us how this access benefits you. Your story matters. 


\section{CJutta Brunnée and Stephen J. Toope ${ }^{*}$ [DRAFT: July 12, 2008]}

This chapter has been accepted for publication and will appear in a revised form, subsequent to appropriate editorial input by Cambridge University Press, in Jutta Brunnée and Stephen J. Toope, Legitimacy and Persuasion in International Law, published by Cambridge University Press.

\section{CHAPTER 1:}

\section{AN INTERACTIONAL THEORY OF INTERNATIONAL LEGAL OBLIGATION}

If we could come to accept what may be called broadly an interactional view of law, many things would become clear that are now obscured by the prevailing conception of law as a one-way projection of authority. ${ }^{1}$

\section{Introduction}

In thinking and writing about international law over the years, we found ourselves increasingly dissatisfied with the prevailing theoretical accounts of the field. None of these accounts, it seemed to us, provided a theoretical framework that fully resonated with the contemporary practice of international law-making and application, satisfactorily explained the strengths and weaknesses of international law, or illuminated the idea of legal obligation in international society. Our goal in this chapter is to sketch out a theory that does meet these challenges - an interactional theory of international law. More specifically, we articulate a theory of international legal obligation. We believe that the key to understanding the role that law plays in international society lies in understanding the nature and operation in practice of legal obligation.

In developing our argument, we draw on the work of one of the foremost legal theorists of the $20^{\text {th }}$ century, Lon Fuller. There is some irony in our turn to a theory of domestic law to think about international law. After all, dutiful incantations of caution notwithstanding, international lawyers and commentators on international law (both friendly and unfriendly) frequently draw on domestic law in their assessments of or prescriptions for its international relative. The resulting picture of international law is rarely good, often ugly, and always distorted. That is precisely why Fuller's theory is so

\footnotetext{
* Jutta Brunnée is Professor of Law and Metcalf Chair in Environmental Law at the Faculty of Law, University of Toronto. Stephen J. Toope is Professor of Law, and President and Vice-Chancellor of the University of British Columbia. We gratefully acknowledge the support of the Social Sciences and Humanities Research Council of Canada. Our thanks for constructive criticism of earlier drafts to David Dyzenhaus, Marty Finnemore, Ellen Hey, Benedict Kingsbury, Rod Macdonald, Mark Pollack, René Provost, Jim Tully, and Antje Wiener. Former research assistants Jaye Ellis and Sean Rehaag, now colleagues, also proved helpful critique, as did our research assistant Umut Öszu.

${ }^{1}$ Lon L. Fuller, The Morality of Law, Rev. ed. (New Haven: Yale University Press, 1969) at 221 [Fuller, Morality of Law].
} 
important for understanding international law. ${ }^{2}$ It reveals that the problem with the domestic law analogy is not necessarily the analogy as such, but the assumptions that commonly shape it. When we assume that the defining features of domestic law - and by extension of all law - are formal enactment by a superior authority, application by courts, and centralized enforcement, we are bound to see international law as a poor cousin. Most importantly, we risk misjudging how law operates in international society, obscuring its potential power, and misdirecting even the best-intentioned efforts to improve it.

As we will explain in this chapter, what distinguishes law from other types of social ordering is not form, but adherence to specific requirements of legality, such as generality, promulgation, non-retroactivity, clarity, and congruence between rules and official action. When norm creation meets these requirements and is matched with norm application that also satisfies the requirements - when there exists what we call a "practice of legality" - actors will be able to pursue their purposes and organize their interactions through law. These features of legality are crucial to generating a distinctive legal legitimacy and a sense of commitment, what Fuller called "fidelity," among those to whom law is addressed. ${ }^{3}$ They create legal obligation. By focusing our attention on markers of legality that are internal to law, Fuller's theory provides a helpful lens through which to reflect on international law. It shows that the formal and hierarchical manifestations typically associated with domestic law, such as tests of "validity," are not sufficient to characterize "law," domestic or international, and indeed may not always be required. ${ }^{4}$

Fuller's legal theory explains law as a purposive enterprise that is both shaped by human interaction and aimed at guiding that interaction in distinctive ways. Law does not depend on hierarchy between law-givers and subjects, but on reciprocity between all participants in the enterprise. By "reciprocity" we mean that law is not a "one-way street." It can exist only when actors collaborate to build shared understandings and uphold a practice of legality. This conception of reciprocity is at the very heart of the interactional account of international law that this book sets forth. Understanding this dynamic is the key to appreciating the nature of legal obligation. In short, we argue that

\footnotetext{
${ }^{2}$ Although Fuller himself did not engage with international law in any detail, he did highlight the implications of legal positivism, and a domestic law optic, for international law. See ibid. at 232-237.

${ }^{3}$ See infra notes 49, 79, 86-87, and 144-145 and accompanying texts.

${ }^{4}$ For an extended critique of the "positivist canon", see Fuller, ibid., esp. Chapter V. In summary, Fuller objected to positivism's preoccupation with the pedigree of rules (sources) and to its attendant hierarchical conception of law creation, which Fuller believed to facilitate authoritarianism. He similarly rejected the idea that law is principally an exercise in "social control," and the linked tendency, evident even in Hart's sophisticated positivism, to view law as coextensive with the power of the state. Much of his criticism retains great force. We would only caution that Fuller's attempt to paint H.L.A. Hart into the corner of those who would support "immoral law" is unfair. One of the explicit desires of the analytical positivists was to provide for an external critique of law rooted in morality. Even if something was law, it could still be wrong. See H.L.A. Hart, "Positivism and the Separation of Law and Morals," (1958) 71 Harv. L. Rev. 593, 618 (Hart, "Positivism"). Fuller simply thought that the critique would be more effective, and loyal to the purposes of legality, if internal rather than external. See infra, notes 68-72 and accompanying text.
} 
the distinctiveness of law lies not in form or in enforcement but in the creation and effects of legal obligation.

The interactional framework enables international lawyers to take a fresh look at their discipline. Taking that fresh look does not mean that we must dismiss as unimportant state consent, or "sources" of international law, the creation of courts and tribunals, or better enforcement mechanisms. Rather, it places these elements in the broader context of the international legal enterprise, so as to better appreciate the roles they play, their potential, and their limitations. It is also reveals that building and maintaining the reciprocity that grounds legal obligation requires sustained effort. As we will illustrate throughout this book, the hard work of international law is never done. Not when a treaty is adopted or brought into force, not when a case is decided by an international court, and not when the WTO Appellate Body imposes a fine or the Security Council enforces a resolution through military force. Each of these examples represents but a step in the continuing interactions that make, re-make or un-make international law.

For example, sources discourse in law provides a useful shorthand to distinguish law from other types of norms, facilitating the daily calculations of participants in a legal system. Although a duly concluded treaty is formally binding on the parties, when it fails to meet the legality requirements we sketched above, the treaty may not generate a sense of obligation. Interactional law helps us to understand that the formal indicator of a rule, in this case a treaty, is not necessarily coextensive with the legality and practice that generates obligation. A particular treaty rule might satisfy the requirement of promulgation, and yet fail to meet other criteria of legality such as clarity. Failure to meet these requirements at the outset does not mean that legality can never be built through the application and development of the treaty. Indeed, gradual build-up will often be the only way to establish genuine and resilient international legality. By the same token, legality can be squandered through careless practice under a treaty. Either way, states' consent to a treaty, its formal existence, and the presence or absence of judicial or enforcement practice are but reference points for efforts to understand, build or maintain the treaty's potential to bind. They each present opportunities for international law; but opportunities must be seized. The concept of a truly "interactional" international law, then, is at once sobering and empowering.

Unlike the prevailing accounts of international law, an interactional understanding of law does not limit effective participation to state actors. The framework explains how diverse actors can interact through law and accommodates both the continuing pre-eminence of states in the international legal system and the rise of non-state actors. In addition, because the requirements of legality are largely procedural in orientation, interactional law is not contingent upon particular political commitments. The fundamental commitment is to enabling participants to pursue their own ends while being guided by law. In other words, while interactional law may well facilitate the legal articulation and pursuit of shared goals, it embraces the diversity of priorities in international society. Interactional law shares this commitment to diversity with some accounts of international 
legal positivism, ${ }^{5}$ particularly the return to a "culture of formalism." 6 But we will argue that interactional international law's internal legality requirements provide stronger safeguards against political domination and power than a purely formal account of international law, precisely because the commitment to autonomous actor choices and diversity is internal to the framework itself (rather than merely an external justification for the framework).

In this chapter, we provide a detailed account of Fuller's legal theory and its implications for international law. First, however, we venture into an adjacent discipline, international relations (IR). In seeking to understand their field, international lawyers have much to gain from some of the central debates among IR scholars. Most international lawyers have consciously or unconsciously assumed the descriptive accuracy of rationalist and positivist explanations for the phenomenon of law. Indeed, rationalism and positivism have been so powerful in their symbiotic relationship that they are not even seen to be theoretically charged, but are commonly viewed as "reality". We draw on IR theory to illuminate the shortcomings of these dominant assumptions about international law and to trace out alternative conceptions of the role and functioning of law in international society.

We argue specifically that the constructivist stream in contemporary IR theory is helpful in explaining how "communities of practice" are created and maintained. ${ }^{7}$ It is through such interaction that actor identities are shaped and shared expectations arise that may ultimately allow for the existence of interactional international law. Constructivist insights reveal how collaborative norm-making is possible. International law can then be seen as a particular iteration of such norm-making, made "legal" through the legitimacy generated by adherence to the internal requirements of legality. Most importantly, constructivism illustrates that these legality criteria are not merely an abstract checklist. As we will explain in more detail in Chapter 2, they are fully realized only if a practice of legality is built and maintained. For now, suffice it to say that shared norms must meet the criteria of legality and be embedded in a sustained practice of legality for reciprocity among participants in the legal system and legal legitimacy to arise. When this happens obligation is created. Constructivist IR theory thus assists our theory of international legal obligation by reinforcing and illuminating crucial aspects of Fuller's interactional understanding of law.

Our interactional theory of international law holds important insights for IR scholars as well as for lawyers. It provides specific criteria of legality, parameters for a practice of legality, and a resultant "legal legitimacy." Together, these elements build a sense of

\footnotetext{
${ }^{5}$ See Benedict Kingsbury, "Legal Positivism as Normative Politics: International Society, Balance of Power and Lassa Oppenheim's Positive International Law" (2002) 13 European Journal of International Law 401 (discussing "political positivism").

${ }^{6}$ See Martti Koskenniemi, From Apology to Utopia: The Structure of International Legal Argument, Reissue with a new epilogue (Cambridge: Cambridge University Press, 2005) at 616 (advocating a "culture of formalism").

${ }^{7}$ See Emanuel Adler, Communitarian International Relations: The Epistemic Foundations of International Relations (London and New York: Routledge, 2005) at 11 [Adler, Communitarian International Relations].
} 
obligation that distinguishes law from other social norms. In so doing, our theory also offers IR scholars, whether rationalist or constructivist, concrete factors to consider as they examine whether and how law "matters" in international affairs. To reiterate, it is obligation rather than form or enforcement that accounts for the distinctiveness of law. ${ }^{8}$ Our ambition is not to articulate another IR theory, or to create hybrid concepts of international "governance." Rather, ours is a legal theory and its central element is a theory of legal obligation, which we hope can contribute to "...the important enterprise of distinguishing law from the morass of approaches to governance in which it threatens to disappear." 10 In an era when it appears - to borrow Yeats' evocative turn of phrase that the "centre cannot hold," 11 when concerns over clashing civilisations drown out the articulation of shared norms at the international level, an interactional approach to law provides concrete guidance in seizing opportunities for effective law making and also shows when law making attempts are likely to fail.

\section{International Relations Theory and International Law}

\subsection{The Domestic Law Optic and Rationalist IR Theory}

Political scientists share with international lawyers a concern to understand how norms function in a horizontal normative order, such as international society. ${ }^{12}$ It is, of course, trite to describe the international order, including international law, as "horizontal" in structure. The essence of the characterization is that there is no legislative or executive hierarchy within the system. Yet, as Michael Barkun argued in the 1960s, social scientists tend to look at international society through the prism of domestic legal systems and to find international law under-developed or wanting. This approach is not surprising. Indeed, it is characteristic of much of the scholarship that, in recent decades, has sought out new insights in cognate disciplines. In looking for such interdisciplinary insights, scholars have often adopted reductionist definitions of the "other" discipline because they have not been actively involved in the constitutive internal disciplinary debates and processes that lead to healthy uncertainty and nuance. In the case of social scientists viewing law, the distorting optic of the domestic law analogy was not

\footnotetext{
${ }^{8}$ See Martha Finnemore, “Are Legal Norms Distinctive?” (2000) 32 New York University Journal of International Law and Politics 699.

${ }^{9}$ Jan Klabbers, “The Relative Autonomy of International Law or the Forgotten Politics of Interdisciplinarity” (2005) 1 Journal of International Law and International Relations 35.

${ }^{10}$ Benedict Kingsbury, "International Law as Inter-Public Law”, unpublished manuscript (on file with authors) at 45.

${ }^{11}$ William Butler Yeats, "The Second Coming" in Michael Robartes and the Dancer (Churchtown, Dundrum: Cuala Press, 1920) 19.

${ }^{12}$ See Martha Finnemore \& Kathryn Sikkink, "International Norm Dynamics and Political Change” (1998) 52 International Organization 887 at 887-88, arguing that normative preoccupations have infused the work of realists, neofunctionalists, scholars of transnational relations, and regime theorists throughout the 1960s, 70s and 80s. See also Mervyn Frost, Ethics in International Relations: A Constitutive Theory (Cambridge: Cambridge University Press, 1996). For a detailed analysis of various ways in which norms function, based on empirical studies in the use of force, see Jeffrey W. Legro, "Which Norms Matter? Revisiting the 'Failure' of Internationalism” (1997) 51 International Organization 31.
} 
exclusively a result of these pitfalls of interdisciplinarity but, as Barkun rightly observed, was actually fed by professional deformation within the discipline of law itself. As we have already suggested, many legal theorists and practicing lawyers have had trouble understanding - much less articulating - how international law can be law, when viewed from the perspective of seemingly hierarchical domestic legal systems.

The reason for what Barkun called the "uncritical appropriation" of the domestic law paradigm is not hard to discover. ${ }^{13}$ It is the strongly positivistic stance of legal theory throughout much of the late nineteenth and twentieth centuries. ${ }^{14}$ For outsiders, even more than for lawyers, positivism promises easy intelligibility: law can be found, defined and labeled. ${ }^{15}$ Yet, if law is viewed, as it is in various strands of positivist thinking, as a hierarchically ordered imposition of social control emanating from a de facto sovereign, ${ }^{16}$ a purely theoretical "Grundnorm," persistently horizontal structure of international law will prove troublesome. International law will either be declared non-existent, or its operation will have to be distorted to fit the theoretical framework. It was therefore natural for IR scholars in the realist tradition, who were trying to cleanse their discipline of all normative ideas, ${ }^{19}$ to ignore international law (or perhaps in their self-conception to grow beyond it). ${ }^{20}$

13 See Michael Barkun, Law without Sanctions: Order in Primitive Societies and the World Community (New Haven: Yale University Press, 1968) at 11; cited in Fuller, Morality of Law, supra note 1 at 237.

${ }^{14}$ A thoughtful description of the appropriation of positivist legal theory by public international lawyers is found in Roberto Ago, "Positivism" in Rudolph Bernhardt, ed., Encyclopedia of Public International Law, vol. 7 (Amsterdam: North-Holland, 1984) 385.

${ }^{15}$ For this formulation of the attraction of positivism in law, we are indebted to Rod Macdonald. A clear example of this tendency is found in the "legalization" project. See supra note 5.

${ }^{16}$ John Austin, Lectures on Jurisprudence, $5^{\text {th }}$ ed. (London: John Murray, 1885) at 86-103. For Austin, the command, to be law, must also be "general" and matched with a potential sanction in the event of noncompliance.

${ }^{17}$ Hans Kelsen, General Theory of Law and State, trans. by Anders Wedberg (New York: Russell \& Russell, 1961); and Hans Kelsen, Principles of International Law (New York: Rinehart \& Company, 1952).

${ }^{18}$ H.L.A. Hart, The Concept of Law (Oxford: Clarendon Press, 1961) at 89-96 and c. 6 [Hart, Concept]; and H.L.A. Hart, Essays in Jurisprudence and Philosophy (Oxford: Clarendon Press, 1983). We do not want to suggest that Professor Hart was committed to a "command theory of law". Indeed, he specifically wished to distance himself from Austin's view that the law was whatever the sovereign (or later Parliament) commanded and could enforce through sanctions. However, Hart's analysis of law remained explicitly hierarchical, with primary rules (imposing obligations) rooted in secondary rules (of recognition, change and adjudication), and the entire system of law nesting in a fundamental "rule of recognition" generated through the practice of state officials.

${ }^{19}$ For a compelling discussion of parallel developments in realism in IR and positivism in law, see Friedrich V. Kratochwil, "How Do Norms Matter?" in Michael Byers, ed., The Role of Law in International Politics (Cambridge: Cambridge University Press, 2000) 35 at 38 et seq.

${ }^{20}$ It is intriguing to contemplate that no less a realist than Hans Morgenthau was "formed" as an international lawyer. See Finnemore \& Sikkink, supra note 12 at 889; and Hans J. Morgenthau, Politics Among Nations: The Struggle for Power and Peace, 2nd ed. (New York: Knopf, 1954) at 8: "Power covers the domination of man by man, both when it is disciplined by moral ends and controlled by constitutional safeguards as in Western democracies, and when it is that untamed and barbaric force which finds its laws in nothing but its own strength and its sole justification in its aggrandizement." Koskenniemi demonstrates convincingly that Morgenthau studied law without any emotional commitment and that his early experiences in the profession only served to confirm his view of "the truth of human society as an unending 
Realists are historically the dominant school in IR theory. For realists of all stripes, law is virtually irrelevant, as is the concept of legal obligation. Relative power and interests determine state conduct. States are seen as homogenous actors that proceed on the basis of a rationally assessed and pursued self-interest. ${ }^{21}$ In the absence of hard enforcement, international law is without effect. For classical realists, the innate human desire for power shapes interaction amongst states, leaving no room for socially generated norms. For neo-realists, the anarchical structure of international society forces states to strategically pursue power in support of their material interests; participation in a regime or adherence to a norm occurs if the net benefits outweigh those of unilateral action. Regimes and norms are seen as reflections of underlying power and interest balances rather than independent factors influencing behaviour. Social norms are entirely subservient to this pursuit. The realist frame of reference has been influential amongst positivist international lawyers, as well as with adherents to the "New Haven School" and, of course, "critical" scholars. More recently, realism has been reasserted as the proper way to understand the "limits of international law" by a strongly nationalist stream of US constitutional law scholarship. ${ }^{22}$

It was equally possible for IR theorists who were actually interested in international law, and its normative force, to misconceive of the potential persuasive power of international law by assuming that its relevance lay in the qualities ascribed to all law by positivist lawyers. "Neo-liberal institutionalists" trace out theoretical terrain that is somewhat more hospitable to international law than are the assumptions of the realists. Law, like other social norms, can provide predictable rules and stable institutional structures. Like realism, neo-liberal IR theory is rooted in rationalist assumptions, but states are not assumed to be homogenous actors. Rather, states must be understood, at least partly, in relation to the institutions in which they are engaged. ${ }^{23}$ Their interactions and deliberations through institutions are important in shaping their self-perceived interests. Actors and their interests are seen as separate from processes of interaction, as largely "given". ${ }^{24}$ Engagement in institutions may affect behaviour but not the "givens" as such.

struggle for power." See Martti Koskenniemi, “Carl Schmitt, Hans Morgenthau, and the Image of Law in International Relations" in Byers, supra note 19, 17 at 18 (citing Hans J. Morgenthau, Scientific Man vs. Power Politics (Chicago: University of Chicago Press, 1946) at 68-71).

${ }^{21}$ See Peter J. Katzenstein, Robert O. Keohane \& Stephen D. Krasner, "International Organization and the Study of World Politics" (1998) 52 International Organization 645 at 658.

22 Jack L. Goldsmith \& Eric A. Posner, The Limits of International Law (Oxford: Oxford University Press, 2005) at 3 ("international law emerges from states acting rationally to maximize their interests, given their perceptions of the interests of other states and the distribution of state power."). The authors' sweeping claims have met with significant criticism from IL and IR scholars with a wide range of theoretical commitments. See, e.g., (2006) 34:2 Georgia Journal of International and Comparative Law (Symposium Issue). See also Chapter 3.

${ }^{23}$ Robert Keohane \& Joseph S. Nye, "Power and Interdependence Revisited" (1987) 41 International Organization 725 .

${ }^{24}$ John G. Ruggie, "What Makes the World Hang Together? Neo-utilitarianism and the Social Constructivist Challenge", (1998) 52 International Organization 855 at 862-863; Alexander Wendt, "Collective Identity Formation and the International State" (1994) 88 American Political Science Review 384 at 384 [Wendt, "Collective Identity”]. 
For neo-liberal institutionalists, legal obligation is simply assumed, ${ }^{25}$ but is never the subject of explicit theorizing. Indeed, obligation seems to become relevant only in combination with other independent explanatory variables, in particular "precision" of rules and "delegation" of legal decision-making. ${ }^{26}$

In short, rationalist IR theory devotes little attention to the foundations of legal obligation, either because law is viewed as a meaningless concept in international relations or because the obligatory quality of law is subsumed within other variables. If material interests drive human behaviour, ${ }^{27}$ then "obligation" holds no analytical interest; the only important question is what incentives and disincentives can be created to cause people and institutions such as states to calculate and pursue their interests in particular ways. International law will not be able to prevail over contrary state interests, since it can only rarely affect interest calculations through adjudication or enforcement. In other words, IR rationalism neatly maps onto the domestic law analogy, treating most international law as weak or even "epiphenomenal." 28 The vicious circle closes when lawyers mistake the dominant theory of international relations for a true account of the way the world actually works. When melded with rationalist assumptions about human motivation, international lawyers' worst fears about the weakness of international law must be equally true.

\subsection{Constructivist Challenges to Rationalism}

In much the same way that the domestic law optic can limit how we think about international law, rationalism can constrain our understanding of international relations. That has been the important message of a more recent strand of IR theory, constructivism, which emerged in part as a reaction to the dominant rationalist explanatory models. ${ }^{29} \mathrm{We}$ argue that constructivism can help us to think more creatively and fruitfully about obligation in law. Constructivism shows how international law can

\footnotetext{
${ }^{25}$ The most comprehensive effort to date by neo-liberals to understand the role of law in international relations specifically "brackets" obligation even though it is said to be one of only three indicators of "legalization". See Kenneth W. Abbott et al., "The Concept of Legalization" (2000) 54 International Organization 401. Their definition of legalization revolves around three characteristics that international institutions may or may not display. "Obligation" is defined as states being "legally bound by a rule of commitment in the sense that their behaviour thereunder is subject to scrutiny under the general rules, procedures and discourse of international law, and often of domestic law". "Precision" is a feature of rules that "unambiguously define the conduct they require, authorize or proscribe". "Delegation" provides third parties with "authority to implement, interpret and apply the rules; to resolve disputes; and (possibly) make further rules".

${ }^{26}$ Ibid. See also Judith L. Goldstein et al., eds., Legalization and World Politics (Cambridge, MA: The MIT Press, 2001).

${ }^{27}$ But see James Fearon \& Alexander Wendt, "Rationalism v. Constructivism: A Skeptical View" in Walter Carlsnaes, Thomas Risse \& Beth Simmons, eds. Handbook of International Relations (London: Sage, 2002) 52 at 58-60 (explaining that rationalism does not necessarily imply materialism, and that for many rationalist scholars peoples' non-material desires or "ideas" too can be causal mechanisms).

${ }^{28}$ See David Bederman, "Constructivism, Positivism, and Empiricism in International Law" (2001) 89 Georgetown Law Journal 469 at 473.

${ }^{29}$ See Antje Wiener, "Constructivism: The Limits of Bridging the Gaps" (2003) 6 Journal of International Relations and Development 252 at 252.
} 
be an important force in socializing actors and shaping their interests and choices. It lends support to our argument that law's obligatory effect results from a commitment or fidelity to law that is generated by adherence to specific traits of legality and maintained by a practice of legality. In turn, as we hope to show, our interactional legal theory can assist constructivism in discerning the distinctive influence exerted by legal obligation.

Constructivists challenge rationalist IR theory to explain the origin of the interests that are said to be determinative of behaviour. Constructivism sees interaction as central to shaping human conduct. ${ }^{30}$ The key claim is that interests are not simply "given" and then rationally pursued, but that social construction of actors' identities is a major factor in interest formation. ${ }^{31}$ Importantly, the ends of social interaction are not predetermined but can be discovered and learned. ${ }^{32}$ Constructivists show how, through interaction and communication, actors generate shared knowledge and shared understandings that become the background for subsequent interactions. In the process, social norms may emerge that help shape how actors see themselves, their world and, most importantly for us, their interests.

None of these commitments reveal any intrinsically idealist bias; they do not assume or even aspire to the creation of a shared global identity or deep value coalescence. For example, John Ruggie and Alexander Wendt are both careful to distance their approaches from any postulated world community or collective conscience. ${ }^{33}$ Emanuel Adler speaks of several, often overlapping, "transnational or international communities," which must be understood as "communities in, and of, practice" and, above all, as "learning communities." 34 Their enterprise does not necessarily imply "a common goal or vision," only that members "must share collective understandings" of "what they are doing and why.",35

Some constructivists could be criticised for retaining too strong a preoccupation with the role of states, seen as largely autonomous, though interacting, actors. Indeed, some strains of constructivism continue to under-value (while always acknowledging as relevant) the roles played by other actors, such as intergovernmental organizations, corporations and NGOs, in shaping world politics. ${ }^{36}$ Others do emphasize the

\footnotetext{
${ }^{30}$ For an overview, see, e.g., Emanuel Adler, "Constructivism in International Relations" in Carlsnaes, Risse \& Simmons, supra note 27, 95 [Adler, "Constructivism in International Relations"].

${ }^{31}$ See Christian Reus-Smit, "Constructivism” in Scott Burchill et al., Theories of International Relations, 3rd ed. (Houndsmills, Basingstoke: Palgrave Macmillan, 2005) 188 at 198-199.

${ }^{32}$ See the account of "social learning" in Adler, Communitarian International Relations, supra note 7 at 19-22.

${ }^{33}$ Ruggie, supra note 24 at 869-70; Wendt, "Collective Identity", supra note 24 at 386 (arguing that "the intersubjective basis of social identities can be cooperative or conflictual").

${ }^{34}$ Adler, Communitarian International Relations, supra note 7 at 11 (emphasis in original).

${ }^{35}$ Ibid. at 22.

${ }^{36}$ See, e.g., Wendt, “Collective Identity”, supra note 24 at 385, “...states remain jealous of their sovereignty and so may resist collective identification more than other actors". For strong objections to the continuing state-centrism of some versions of constructivist regime theory, see Robert Wolfe, "Rendering unto Caesar: How Legal Pluralism and Regime Theory Help in Understanding 'Multiple Centres of
} 
participation of these diverse actors. For example, Adler's communities of practice "cut across state boundaries and mediate between states, individuals, and human agency, on one hand, and social structures and systems, on the other.",37

Returning to the central idea that actors' identities are shaped by social interaction, constructivists also stress that identities are not monolithic. Actors may maintain and foster multiple, though typically overlapping, identities depending upon the pattern of interactions into which they enter. ${ }^{38}$ Consider the multiple identities of France, for example, as a nation, as European, as a "great power", residually as a colonial power, or as a member of the Security Council. ${ }^{39}$ None of these examples make sense in the absence of social interaction. Even as a "nation," France's identity is constructed through internal (regional) interaction, but also through interactions with other nations. ${ }^{40}$ This is not to deny that material elements are also relevant to identities and interests. France's identity is shaped as well by its location and geography, its population size and density, its natural resources or need for resources, and a myriad of other material factors. Of course, constructivists would maintain that "ideas" still play a significant role in giving meaning to these material factors. ${ }^{41}$ Either way, brute facts and social facts both shape identity and interest. ${ }^{42}$

The key for understanding international relations in constructivist terms is that the interaction of states and other actors ("agents") builds and modifies social "structures." Echoing the structuration theory of Anthony Giddens and Roy Bhaskar, ${ }^{43}$ constructivists emphasise the "duality of structure": structures constrain social action, but they also enable action, and in turn are affected and potentially altered by the friction of social action against the parameters of the structure. ${ }^{44}$ In other words, agents and structures are mutually constituting, and both are inherently social. Emanuel Adler explains:

Power"' in Gordon Smith \& Daniel Wolfish, eds., Who is Afraid of the State? Canada in a World of Multiple Centres of Power (Toronto: University of Toronto Press, 2001) 259.

${ }^{37}$ See Adler, Communitarian International Relations, supra note 7 at 15.

${ }^{38}$ Alexander Wendt, "Anarchy is What States Make of It: The Social Construction of Power Politics" (1992) 46 International Organization 391 at 398 [Wendt, "Anarchy”]; Wendt, "Collective Identity”, supra note 24 at 385; and Adler, supra note [?] at 265 (using the term "multiple allegiances").

${ }^{39}$ Identities are not constantly shifting, however, so interests may also retain a consistent flavour, allowing for predictability. See Wendt, "Anarchy" supra note 38 at 411 and 418.

${ }^{40}$ Alexander Wendt distinguishes between states" "personal" or "corporate" identities, which are rooted in domestic politics and are "ontologically prior to the states system," and their "social" identities, which develop through interaction with other actors in the international arena. See Social Theory of International Politics (Cambridge: Cambridge University Press, 1999) at 198 and 224-225.

${ }^{41}$ For a detailed argument, see Wendt, Social Theory, ibid. at 92-135.

${ }^{42}$ See John Searle, The Construction of Social Reality (London: Penguin, 1995) at 2.

${ }^{43}$ Anthony Giddens, The Constitution of Society: Outline of the Theory of Structuration (Cambridge: Polity Press, 1984); Roy Bhaskar, The Possibility of Naturalism: A Philosophical Critique of the Contemporary Human Sciences (Brighton: Harvester Press, 1979).

${ }^{44}$ See Giddens, ibid. at 25-29. See also Anthony Giddens, "Agency, Structure” in Anthony Giddens, ed., Central Problems in Social Theory (Berkeley, CA: University of California Press, 1979) 49 at 69. Alexander Wendt, "The Agent-Structure Problem in International Relations" (1987) 41 International Organization 335; Adler, Communitarian International Relations, supra note 7, at 5-6 and 11-12; ReusSmit, supra note 31 at 197. 
As webs of meaning sustained by social communication, intersubjective structures constitute the content and boundaries of identities, practices, and institutions. Without individuals' minds, of course, there would be no intersubjective webs of significance; but without these webs, minds would be nearly empty and there would be no institutions. $^{45}$

For present purposes, the main point is that the "intersubjective structures" to which Adler refers "have different components that help in specifying the interests that motivate action: norms, identity, knowledge, and culture. ${ }^{, 46}$ In highlighting both the social creation of norms and their social impact, constructivism thus opens the way for an examination of the role of law in international society. Constructivist IR scholars have not focussed specifically on the question of legal obligation, though they are generally interested in the role of law in international society. We believe, however, that constructivist insights into the way in which norms shape actor identities help us to appreciate how law can matter, in part because it is obligatory and anchored in a particular understanding of legal legitimacy. To understand how this is so, we need to connect the insights of constructivist IR theory to the work of Lon L. Fuller.

\section{The Contributions of Lon Fuller}

Fuller interests us because he cared deeply about two key ideas: the generation of social norms through interaction and the sense of responsibility that arises only from the human ability to reason with norms. On the first idea, one could adopt constructivist terms to explain that Fuller believed in the mutuality of agency and social structure. To understand how law works, we need to pay attention both to autonomous actors and to the institutions through which they interact. This dual focus highlights that Fuller's commitment to "autonomy," is best understood in relational terms - as human interaction in social institutions - a constructivist recasting that allows for social and political diversity. ${ }^{47}$ Analyzing law in this way cuts to the heart of the greatest challenge facing international law: to construct normative institutions while admitting and upholding the diversity of peoples in international society. Fuller explained law, and the rule of law, in

\footnotetext{
${ }^{45}$ Emanuel Adler, “Barry Buzan's Use of Constructivism to Reconstruct the English School: 'Not All the Way Down”” (2005) 34 Millennium: Journal of International Studies 171 at 176.

${ }^{46}$ Katzenstein, Keohane \& Krasner, supra note 21 at 679. See also Finnemore \& Sikkink, supra note 12 at 891 , note that it is common for constructivists to talk of "norms" when they mean "institutions," the latter being properly viewed as aggregations of interrelated norms. Institutions, both formal and informal, are simply particular cases of "social structure."

${ }^{47}$ Similar reinterpretations of autonomy are found in political theory and legal philosophy. See, e.g., the work of Jennifer Nedelsky, including "Communities of Judgment and Human Rights" (2000) 1 Theoretical Inquiries in Law 245; or "Judgment, Diversity, and Relational Autonomy" in Ronald Beiner \& Jennifer Nedelsky, eds., Judgment, Imagination, and Politics: Themes from Kant and Arendt (Lanham: Rowman \& Littlefield, 2001) 103.
} 
a manner that did not require fundamental shared commitments to a single political morality, nor the existence of centralized political authority. ${ }^{48}$

Fuller's conception of the rule of law connects us to his second core idea - that reasoning with norms helps to create a sense of responsibility. Fuller's approach to theory was utterly practical. He wanted to show that law enables human beings to organize their lives and their relationships with each other while limiting the potential abuse of authority by insisting on "criteria of legality" that constrain arbitrary exercises of power. When citizens are enabled to reason with norms, they can begin to develop what Fuller called "fidelity" not just to particular norms, but to the system of law itself. ${ }^{49}$ We will shortly explain how that fidelity is fostered, and demonstrate that it is central to the legal concept of obligation.

Fuller's description of law is forthright, but does not constitute a definition: law is "the enterprise of subjecting human conduct to the governance of rules." ${ }^{, 50}$ The description of law as an "enterprise," a term borrowed from the sphere of economic life, ${ }^{51}$ is meant to signify law's "purposive" aspect, its incomplete and aspirational (or even entrepreneurial) quality. For Fuller, law is best viewed as a continuing challenge rather than as a finished project. $^{52}$ Law is formed and maintained through continuing struggles of social

\footnotetext{
${ }^{48}$ For a similar argument, see Terry Nardin, "Legal Positivism as a Theory of International Society" in David R. Mapel \& Terry Nardin, eds., International Society: Diverse Ethical Perspectives (Princeton, NJ: Princeton University Press, 1998) 17 at 24 and 31. But see Frederick G. Whelan, "Legal Positivism and International Society" in ibid. 36, at 50 (suggesting that the idea that this conception of the rule of law "can accommodate states with different cultures" ultimately "combines conceptions of legality with a substantive liberal philosophical principle").

${ }^{49}$ Ibid. at 39-41; and especially Lon L. Fuller, "Positivism and Fidelity to Law - A Reply to Professor Hart" (1958) 71 Harvard Law Rev. 630.

${ }^{50}$ Fuller, Morality of Law, supra note 1 at 106. On Fuller's lack of interest in definitional exercises, see Kenneth I. Winston, "Three Models for the Study of Law" in Willem J. Witteveen \& Wibren van der Burg, eds., Rediscovering Fuller: Essays on Implicit Law and Institutional Design (Amsterdam: Amsterdam University Press, 1999) 51 at 69 (quoting Fuller criticizing the definitional fixations of lawyers: "I know of no other field in which we consume so much energy and adrenaline in proposing and attacking definitions.").

${ }^{51}$ Although Fuller's work was rooted in the liberal market economics of mid-twentieth century America, he was by no means an apologist for unbridled capitalism. Most importantly, Fuller did not believe that cooperation could only be produced through rational maximization of self-interest. See Jeremy Waldron, "Why Law - Efficacy, Freedom, or Fidelity?" (1994) 13 Law and Philosophy 259 at 271; Winston, supra note 50 at 65; Joseph Vining, "Fuller and Language" in Witteveen \& van der Burg, supra note 50, 453 at 471 (distinguishing law from games); David Luban, "Rediscovering Fuller's Legal Ethics" in Witteveen \& van der Burg, supra note 50, 193 at 208 (arguing that Fuller's economics is completely distinct from the "law and economics" school); and Karol Sołtan, "A Social Science That Does Not Exist" in Witteveen \& van der Burg, supra note 50, 387 at 394 (noting that Fuller is part of a tradition resistant to rational choice theory and its assumptions about human motivation). He was not even a utilitarian, being far too preoccupied with moral theory, and eschewing instrumentalism. See Pauline Westerman, "Means and Ends" in Witteveen \& van der Burg, supra note 50, 145.

${ }^{52}$ Fuller, Morality of Law, supra note 1 at 106 and 145. See also Lon L. Fuller, "American Legal Philosophy at Mid-Century” (1954) 6 Journal of Legal Education 457 at 467 (“... law is not a datum, but an achievement that needs ever to be renewed").
} 
practice. ${ }^{53}$ Law, therefore, "is the work of its everyday participants, a continuous effort to construct and sustain a common institutional framework to meet the exigencies of social life in accordance with certain ideals." ${ }^{, 54}$ Note the strong parallel to Adler's constructivist description of "communities of practice" as a source for all social norms. It follows that law can exist by degrees, so it is possible to talk about law that is being constructed; law is not an all-or-nothing proposition. ${ }^{55}$ Fuller admits that this continuum of legality ${ }^{56}$ can make it difficult to know exactly when a system, or a particular rule, has made the transition from social to legal normativity, but he proposes a specific approach to assessing the strength of legality, which we will shortly discuss. ${ }^{57}$

Despite the use of the word "subjecting" in Fuller's description of law, Fuller rejected a command model of legal effectiveness. Law is not grounded in the will of the sovereign or of Parliament; it is not simply the fiat of state power, nor is it rooted in a hierarchy of rules. ${ }^{58}$ Humans are not subjected to law; human conduct is subjected to the governance of rules. No law, even law in seemingly hierarchical state systems, is merely the imposition of authority (read as "power") from above. ${ }^{59}$ That is because, when

\footnotetext{
${ }^{53}$ Fuller, Morality of Law, supra note 1 at 129 . Fuller is indebted to Aristotle for the strong practical orientation of his approach to norms and morality. Aristotle, [The Nicomachean] Ethics, trans. by J.A.K. Thomson (Harmondsworth: Penguin 1976) X:ix, at 335 et seq., especially 340-41. See also Peter R. Teachout, “'Uncreated Conscience': The Civilizing Force of Fuller's Jurisprudence” in Witteveen \& van der Burg, supra note 50, 229 at 240; Gerald J. Postema, "Implicit Law" (1994) 13 Law and Philosophy 361, reprinted in Witteveen \& van der Burg, supra note 50, 255 at 256 [Postema, "Implicit Law"]; and Roderick A. Macdonald, "Legislation and Governance" in Witteveen \& van der Burg, supra note 50, 279 at 286-87. Oddly enough, Fuller's understanding of law as social struggle serves as a link between his work and that of the consummate realist, Hans Morgenthau, who also rejected positivism because of its lack of connection to actual social forces shaping humanity's structures and fate. However, this connection is superficial, for Morgenthau would never have accepted Fuller's conclusions, most pointedly, that legal norms are tested in part through adherence to an internal morality. For Morgenthau, "realism" dictated that law could be defined only by the psychology and sociology of force or sanction. See Koskenniemi, supra note 20 at 22-24.

${ }^{54}$ Winston, supra note 50 at 63.

${ }^{55}$ Fuller, Morality of Law, supra note 1 at 117 and 123 (rejecting a bright line distinction between law and non-law); and 122 ("[B]oth rules of law and legal systems can and do half exist. This condition results when the purposive effort necessary to bring them into full being has been, as it were, only half successful.").

${ }^{56}$ In earlier work we described the idea of such a continuum in a discussion of what we called "contextual regimes." See Jutta Brunnée \& Stephen J. Toope, "Environmental Security and Freshwater Resources: Ecosystem Regime Building” (1997) 91 American Journal of International Law 26 [Brunnée \& Toope, "Environmental Security"].

${ }^{57}$ Fuller, Morality of Law, supra note 1 at 131. See also the discussion of the "internal morality" of law infra notes 68-72 and accompanying text.

${ }^{58}$ Fuller, Morality of Law, ibid. at 63 (warning against a confusion between fidelity to law and "deference for established authority"), 107 (distinguishing the rule of law from public order), 115 and 148 (emphasizing that lawful authority is the "product of law", not its precursor), 168 (explaining why not all governmental action is "legal" in nature), 110 (rejecting the "pyramidal structure of state power" as the essence of law), and 133 to 145 (discussing and discarding Hart's normative hierarchy).

${ }^{59} \mathrm{Ibid}$. at 221 and 233. Neither official texts nor official's acts can be treated as exclusive sources of normativity. See Macdonald, supra note 53 at 305 and 309. For a characteristic positivist focus upon explicit texts as the primary source of legal obligation, see Thomas M. Franck, The Power of Legitimacy Among Nations (Oxford: Oxford University Press, 1990) at 42 and 52 [Franck, Legitimacy].
} 
understood as a purposive activity, law depends for its existence "on effective interaction and cooperation between citizens and lawmaking and law-applying officials."60 For Fuller, this reciprocity was necessary because of the fundamental autonomy of human beings. Indeed, one might say that Fuller's entire theory was directed at ensuring that autonomy. ${ }^{61}$ However, we will return shortly to our argument that "autonomy" need not be understood in purely individualistic and should instead be conceptualised in social terms. As we shall see, Fuller always balanced "autonomy" and a fundamental need for human communication. Citizens are not merely subjects but are interacting agents creating law through specific processes of communication.

Fuller's "interactionism"62 is central to the upholding of autonomy. Law guides human action by addressing reasons for action to agents, but these reasons are of a general nature, and agents must reason further with the norms to apply them in specific contexts, characteristically relying upon analogy to argue a point. ${ }^{63}$ It is therefore essential that relatively stable patterns of expectation emerge both amongst the governed and between the governed and the governing. But relatively stable expectations or, to adopt constructivist language, shared understandings, are only likely to arise from repeated social practice. Postema refers to this idea as the "congruence thesis," emphasizing that "legal norms and authoritative directives can guide self-directed social interaction only if they are broadly congruent with the practices and patterns of interaction extant in the society generally." 64

It follows that law is not dependent upon force for its existence, ${ }^{65}$ nor is it best imagined as an exercise of authority, if by "authority" one means "power over" others. ${ }^{66}$ Law is

\footnotetext{
${ }^{60}$ Postema, "Implicit Law", supra note 53 at 260. See also Fuller, Morality of Law, supra note 1 at 194195 (“The quality and terms of the parties' emergent relationship - its 'laws' if you will - constitute an important social reality, but it is a reality brought into being and kept alive by purposive effort and by the way each of the parties interprets the purposes of the other."); and 209 (arguing that in a legal system "the existence of a relatively stable reciprocity of expectations between lawgiver and subject is part of the very idea of a functioning legal order".) See also Lon L. Fuller, "Human Interaction and the Law" (1969) 14 American Journal of Jurisprudence 1, reprinted in Kenneth I. Winston, ed., The Principles of Social Order: Selected Essays of Lon L. Fuller, Rev'd ed. (Oxford: Hart, 2001) 211 at 231-33; and Lon L. Fuller, “A Reply to Professors Cohen and Dworkin" (1965) 10 Villanova Law Review 655 at 661.

${ }^{61}$ Colleen Murphy, "Lon Fuller and the Moral Value of the Rule of Law" (2005) 24 Law and Philosophy 239.

${ }^{62}$ See Fuller, Morality of Law, supra note 1 at 221, 237 and 241. See also the discussion in Postema, "Implicit Law", supra note 53 at 256-65 and 270.

${ }^{63}$ See Vaughan Lowe, "The Politics of Law-Making: Are the Method and Character of Norm Creation Changing?" in Byers, supra note 19, 207 at 210, n. 5 and 214. Lowe's approach to the "character" of norm creation is analogous to Fuller's, for Lowe emphasizes the power of "interstitial norms" in driving change within the international legal system, ibid. at $212 \mathrm{et} \mathrm{seq.} \mathrm{Of} \mathrm{course,} \mathrm{the} \mathrm{idea} \mathrm{that} \mathrm{norms} \mathrm{must} \mathrm{inevitably} \mathrm{be}$ interpreted, and that rules must be conditioned by context to be equitable is deeply rooted in Aristotelian thought. See Jonathan Barnes, "Introduction" in Aristotle, supra note 53, 9 at 21; and Aristotle, ibid. at V:iii, at 177; and V:x, at 198.

${ }^{64}$ Postema, "Implicit Law", supra note 53 at 265.

${ }^{65}$ Fuller, Morality of Law, supra note 1 at 108 and 139 (though force may be usefully exercised in some circumstances). See also Lon L. Fuller, The Law in Quest of Itself (Chicago: The Foundation Press, 1940) at 118 [Fuller, The Law in Quest of Itself], arguing that social order is about freedom from violence, so
} 
"authoritative," but only when it is mutually constructed. Finally, in a system that is reciprocally generated, issues of interpretation occupy "a sensitive, central position" in the legal imagination. ${ }^{67}$

Within a conception of law that is non-hierarchical, not defined by the use of force, and mutually constructed by actors who may be both governors and governed (creators and subjects of law), what gives rise to a legal norm, distinguishing it from other social norms? Here Fuller posits his most controversial thesis: one knows law by requiring strong adherence to its "internal morality."68 Fuller's concept of "internal morality" was rooted in his belief that certain conditions must be in place to allow human beings to pursue their purposes through law and for law to guide their actions and interactions. ${ }^{69}$ If the internal morality of the law is not fulfilled, if the conditions are not met, then the process of law creation, be it through legislation, adjudication or negotiation, is fundamentally flawed and, we will argue, lacks distinctive legal legitimacy. The formation of a simple contract provides a useful example. If the imbalance of power between the parties is great, if there is no real opportunity for negotiations, and if no true reciprocity is evident, then one really has not created a contract at all, but has merely acted in the form of "contract."

cannot be defined by the exercise of violence [Page 118 discusses positivism's indebtedness to the scientific method, but doesn't seem to make reference to violence. I haven't been able to locate any references to violence in the immediately preceding and following pages, and the index is not helpful.]. The lack of emphasis upon coercion is one of the key elements distinguishing Fuller from American Legal Realists. Their interest in "practice" was largely limited to predicting the exercises of power by official actors (especially judges), matched with the enforcement capacity of the state. See Oliver Wendell Holmes, Jr., "The Path of the Law" (1897) 10:8 Harvard Law Review 457.

${ }^{66}$ Postema, "Implicit Law", supra note 53 at 272. See also Andrew Hurrell, "International Law and the Changing Constitution of International Society" in Byers, supra note 19, 327 at 328. This claim is more radical than the denial of "force" as a central element of the definition of law, for even positivists such as Hart wanted to jettison the reliance upon force inherent in Austinian command theories of law. See Winston, supra note 50 at 60 . But to move "authority over subjects" from the centre of our preoccupations profoundly challenges any hierarchical understandings of law. Postema correctly emphasizes that both force (or coercion), and authority are "salient" for Fuller, but he moves them away from "the center of our conceptions of law".

${ }^{67}$ Fuller, Morality of Law, supra note 1 at 91.

${ }^{68}$ Fuller also posited the existence of a weak "external morality" that was the repository of a limited substantive conception of justice and fairness. Fuller, Morality of Law, supra note 1 at c. 2 and 4. [The ambiguity introduced by Fuller's references to external morality has been highlighted by both friendly and critical commentators. See Westerman, supra note 51 at 155 (observing, while otherwise sympathetic to Fuller's account, that "his distinction between internal and external morality seems to reintroduce the distinction between technicity and morality" and, along with his endorsement of a "procedural natural law," "seems to strengthen the interpretation that Fuller conceives of law primarily as ... a means to ... external "substantive aims"'). That appears to be precisely the interpretation arrived at in critiques such as that by Frederick Schauer, "Fuller's Internal Point of View" (1994) 13 Law and Philosophy 285 at 296 (noting that "if the argument for calling Fuller's internal procedural requirements moral ones is the belief in their probabilistic instrumental relationship to substantive or external morality, then there is not that much distance between Fuller's position ... and a more traditional natural law position").]

${ }^{69}$ See David Dyzenhaus, "Fuller's Novelty" in Witteveen \& van der Burg, supra note 50, 78 at 97. 
Fuller's linkage of law and morality raised storms of protest. It is a first principle of positivism that "the law that is" should be viewed separately from "the law that ought to be," that law and morality are distinct areas of human endeavour with different structures of argument. ${ }^{70}$ But Fuller never argued that law and morality are co-extensive. ${ }^{71}$ Indeed, he recognized that legal norms are distinguishable by the explicit responsibilities they impose, and we add by the specific sense of obligation that they generate. However, the idea that law is constructed, that it can partly exist, makes it hard to distinguish the exact point when broad moral concerns in society become legal concerns. For Fuller, the key to the distinction lies in eight internal criteria of legality - his "internal morality of law" that apply to both individual rules and systems of rule-making. Legal norms must be general, prohibiting, requiring or permitting certain conduct. They must also be promulgated, and therefore accessible to the public, enabling citizens to know what the law requires. Law should not be retroactive, but prospective, enabling citizens to take the law into account in their decision-making. Citizens must also be able to understand what is permitted, prohibited or required by law - the law must be clear. Law should avoid contradiction, not requiring or permitting and prohibiting at the same time. Law must be realistic and not demand the impossible. Its requirements of citizens must remain relatively constant. Finally, there should be congruence between legal norms and the actions of officials operating under the law. ${ }^{72}$

It is fair to say that for Fuller, identifying the distinctive obligatory effect of law was not a major concern. Given his strong pluralism, his interest in the wide variety of mechanisms of normative social ordering outside law, Fuller was never much concerned to trace out a fixed boundary between law and other forms of social normativity. ${ }^{73}$ Our view is somewhat different. For international society some distinction between legal obligations and broader social norms is crucial in upholding an admittedly weak rule of law tradition. ${ }^{74}$ What is more, despite his refusal to highlight the issue, we think that one can nonetheless extrapolate an approach toward the relative specificity of law, what we call its obligatory quality, from Fuller's arguments. ${ }^{75}$ In an interactional theory of law,

\footnotetext{
${ }^{70}$ See, e.g., Hart, "Positivism", supra note 4 at 606; and Ronald Dworkin, "Philosophy, Morality, and Law - Observations Prompted by Professor Fuller's Novel Claim” (1965) 113 University of Pennsylvania Law Review 668. Hart also thought that positivism's separation of law and morals properly emphasized the nature of law as authority rooted in criteria of validity found ultimately in the rule of recognition. See the posthumously published postscript to the second edition of Concept. See The Concept of Law, $2^{\text {nd }}$ ed. (Oxford: Oxford University Press, 1994) at 238 et seq.

${ }^{71}$ Given Fuller's commitment to the "morality of law," he has always been associated with the natural law tradition. He acknowledged this connection, but distinguished his "procedural natural law" from substantive natural law conceptions. Fuller, Morality of Law, supra note 1 at 96-97; and see infra note 83 and accompanying text.

${ }^{72}$ See Murphy, supra note 61 at 240-241.

${ }^{73}$ Fuller, Morality of Law, supra note 1 at 131.

${ }^{74}$ We believe that the distinction between being legally obliged to follow a rule and being encouraged to do so through social pressure alone is important to the political calculations of international actors. In addition, a theory of legal obligation helps social actors to take strategic decisions about how to act so as to shape, uphold or change norms. See further in Chapter 3 on Interactional Law and Compliance.

75 The closest Fuller comes to discussing the distinction between law and other forms of social normativity is in the concluding chapter of The Law in Quest of Itself, supra note 65. See also, but more opaquely, Lon L. Fuller, "Freedom as a Problem of Allocating Choice" (1968) 112 Proceedings of the American
} 
law can be distinguished from other forms of social normativity by the specific type of rationality apparent in the internal processes that make law possible. This rationality is dependent upon reasoned argument, reference to past practice and contemporary social aspirations, and the deployment of analogy. When the eight criteria of legality are met, and when this particular rationality is evident, law will tend to attract its own adherence. As we already noted, Fuller called this effect "fidelity" to law, ${ }^{76}$ and others have termed it law's "loyalty-advantages" 77 or the "self-bindingness of law."78 Legal "obligation" is therefore best viewed as an internalized commitment and not as an externally imposed duty matched with a sanction for non-performance.

Fidelity is generated, and, in our terminology obligation is felt, because adherence to the eight criteria of legality (a "practice of legality") produce law that is legitimate in the eyes of the persons to whom it is addressed. To take two simple examples: no-one really enjoys paying taxes; nor do riparian states readily concede their "right" to the use of water. However, when tax law is seen to be fair, the rules relatively understandable and when the rules are seen to be applied by officials in an equitable manner, most people will voluntarily pay their taxes. The contrary is equally true, and in many states with a weak set of "rule of law" principles, the rate of effective tax collection is low. ${ }^{79}$ Similarly, our work on shared water resources has demonstrated that when states participate in norm-creation through open interactional processes, communities of practice are created that allow for the evolution of stronger normative regimes, as has recently been the case in the Nile Basin. ${ }^{80}$ To reiterate, a distinctive form of legitimacy is internal to interactional law; it is not an external measure of political value or preference.

The criteria of legality suggested by Fuller are largely uncontroversial. Few lawyers or legal theorists would argue against promulgation, clarity or predictability in rules. In fact, even Fuller's primary opponent, H.L.A. Hart, agreed that the criteria were important. ${ }^{81}$ However, in well-known objections to Fuller's characterization of his eight tests of legality as "moral", both Hart and Joseph Raz argued that the criteria were purely

Philosophical Society 101; and Fuller, Morality of Law, supra note 1 at 33-38 (on mythical King Rex coming to understand an interactional legal order as relying on internalized conceptions of bindingness).

${ }^{76}$ See supra note 49 and accompanying text. Even Fuller's principal intellectual opponent, Professor Hart, emphasized that norms required a sense of internally felt obligation on the part of officials who must follow a rule, but in Hart's theory this was more a measure of effectiveness, for rules derived their force from their existence in a normative hierarchy. See Hart, Concept, supra note 18, passim.

${ }^{77}$ Waldron, supra note 51 at 282.

${ }^{78}$ RA Macdonald, personal communication with authors.

79 ??See, e.g., Leslie Book, “The Collection Due Process Rights: A Misstep or Step in the Right Direction?" (2004) 41 Houston Law Review 1145 (arguing that enhanced reliance upon due process principles in tax collection ought to be understood as a fundamentally salutary development, bringing principles of administrative and constitutional law to bear upon the US's historically unconstrained Internal Revenue Service).

${ }^{80}$ See Brunnée \& Toope, "Environmental Security", supra note 56.

${ }^{81}$ Hart considered the criteria to be important for efficient law, acknowledging also that they were descriptive of the rule of law. However, he did not consider them to be central to concept of law as such and, crucially, he did not consider them to be moral in nature. See Hart, Concept, supra note 18 at 202 and 207; and H.L.A. Hart, Essays in Jurisprudence and Philosophy (Oxford: Clarendon Press, 1983) at 350. 
about efficacy. Raz offered up the metaphor of a knife. As a knife becomes more and more blunt, it ceases to serve its function, and at some point can no longer be called a knife. So Hart and Raz agreed with Fuller that, when certain criteria are not met, law ceases to be law. But they considered this question to be a purely instrumental, and not a moral, issue. Hart and Raz are positivists who argued strongly that moral concerns were necessarily external to law. But Raz's very metaphor reveals the difficulty in treating law as essentially functional and instrumental, without internal "moral" content. There are circumstances when a "knife" can still be a knife even when it is entirely blunt, or when it cannot be used for a functional purpose. First of all, a knife can have tremendous symbolic value: when a small boy asks his father for a knife, the father might be reluctant to give the requested Swiss Army knife. But a beautiful "jewel-encrusted" dagger bought on vacation for a few dollars at a Tunisian market might be very much appreciated by the boy as a symbol of "knife" even with its dull, functionless blade. Similarly, the Kirpan worn by orthodox Sikh males may be wrapped in a ceremonial casing that makes it impossible to draw the knife. That has not stopped some worried parents from trying to have Kirpans banned from schools in Western countries. " 82 "Knife" has value aside from function, and law has internal value aside from its instrumentality: that was one of Fuller's central insights.

We nevertheless acknowledge that describing the criteria of legality as "moral" can cause confusion, because of the link to natural law theory, and a resulting sense that Fuller may be requiring too much social agreement as to the ends of law. Given the long history of scholarly debate, people tend to assume that natural law necessarily implies a deep commitment to a range of substantive values. For Fuller, it did not. Fuller himself described his theory as a "procedural version of natural law." 83 By that he meant that the "morality" to which he refers is contained primarily within the procedures of law itself in the eight criteria of legality. One could describe this procedural natural law as a "weak" variety of natural law, in the sense that it contains only a very limited range of substantive commitments. Indeed, for Fuller, there were only two essential commitments in law: human autonomy and communication or interaction. It is crucial that these values themselves interact, so that, as we suggested above, Fuller's "autonomy" was an autonomy created and supported through communication. For Fuller, it is only to the extent that law supports autonomy while facilitating social interaction that law pursues "moral" ends. ${ }^{84}$

\footnotetext{
${ }^{82}$ For details regarding a recent Canadian attempt to ban the wearing of kirpans in schools, see Richard Blackwell \& Terry Weber, "Supreme Court Rules Kirpans Okay in School" Globe and Mail (2 March 2006), online at: http://www.theglobeandmail.com/servlet/story/RTGAM.20060302.wkirpan0302/BNStory/National/ (last accessed on February 12 2008). For details regarding similar attempts in a number of US states, see online at: http://www.sikhcoalition.org/LegalUS0.asp (last accessed on February 12 2008).

${ }^{83}$ Fuller, Morality of Law, supra note 1 at 96-97 ("What I have called the internal morality of law is ... a procedural version of natural law ... [it is] concerned, not with the substantive aims of legal rules, but with the ways in which a system of rules for governing human conduct must be constructed and administered if it is to be efficacious and at the same time remain what it purports to be.").

${ }^{84}$ Dyzenhaus, supra note 69 at 97 (Noting that, for Fuller, "[t] $\mathrm{t}$ he moral foundation of law has to be manifest in the institutions of law so that law can fulfil its moral task - the promotion of interaction between individuals subject to the law ...").
} 
Fuller's particular conception of the "moral" content of law requires further exposition. He insisted that his internal criteria were moral in part because they upheld and promoted agency; they enabled citizens to reason with law to make choices about their own lives and appropriate conduct. Therefore "the rule of law provides some normative grounds for thinking that citizens have a moral obligation to obey the law." 85 Note that the obligation to obey is self-generated - "fidelity" - and is rooted in a sense of legitimacy gained primarily from upholding the "internal morality of law" (the eight criteria of legality). We concur that promoting agency, and therefore responsibility, is an important social goal. But, as we have already hinted, in respect of international law the commitment to agency and autonomy, when linked to the second "moral" commitment to communication or interaction, implies that another good is embedded in the conditions of legality: respect for the diversity peoples. If fidelity to law is generated by the adherence to the criteria of legality, then agents are willing to have their behaviour guided by the promulgated rules even if they disagree with them on substantive moral grounds. ${ }^{86}$ Or, as Jeremy Waldron put it, the crucial point is that fidelity to law "is predicated on what law is, not just on what it is used for." ${ }^{, 87}$ So, perhaps despite his own preference to support the autonomy of individuals as an overarching moral value, Fuller actually helps us to see how law is possible in societies where diverse moral ends are being pursued by citizens or peoples, including even challenges to individual autonomy.

The second internal "moral" element of law is rooted in an assumption about human nature, which is that the main goal of human life is not mere survival, but "maintaining communication with our fellows." 88 Indeed, humanity's survival has been predicated upon the acquisition and transmission of knowledge, and upon a conscious and deliberate coordination of effort amongst human beings. ${ }^{89}$ Following Ludwig Wittgenstein, Fuller argues that "[h]ow and when we accomplish communication with one another can expand or contract the boundaries of life itself." 90 Constructivists would add that it is through

\footnotetext{
${ }^{85}$ Murphy, supra note 61 at 242.

${ }^{86}$ But see also Dyzenhaus, supra note 69 at 98 (suggesting that "in particular legal orders, that is, in liberal democratic societies, one will find that allegiance is possible only if the legal order respects the libertyloving character of the citizenry.").

${ }^{87}$ Waldron, supra note 51 at 275.

${ }^{88}$ Fuller, Morality of Law, supra note 1 at 185 . See also ibid. at 210: "[L]aw ... is basically a matter of providing the citizenry with a sound and stable framework for their interactions with one another,..." On the role of communication in human life see also the following, evocative passage in Tim Blanning, The Pursuit of Glory: Europe 1648-1815 (London: Allen Lane, 2007) at 3: "Communication is central to human existence. Apart from basic physical functions such as eating and defecating, waking and sleeping, nothing is more central. Whether the form it takes is symbolic, as in speech, or physical, as in travel, it is communication between people and people, or between people and places, that weaves the social fabric."

${ }^{89}$ Ibid. at 185-86. Winston argues that Fuller's essentially benign view of human nature is what led him to "conceive of law not as coercive and controlling but as facilitative and enabling." Winston, supra note 50 at 58. See also Aristotle, supra note 53, I:vii, at 74, VIII:1, at 258, on humans as "social beings" who live to communicate, and to develop friendships.

${ }^{90}$ Fuller, Morality of Law, supra note 1 at 186. Or in Macdonald's words, "[o]ur acts and our sayings are both the reflection of, and the aspiration towards, normativity." Macdonald, supra note 53 at 305 . We noted above that this communicative focus in Fuller connects as well to Anthony Giddens and Ray
} 
communication and social practice that actors' identities are shaped and their world acquires meaning. ${ }^{91}$

Fuller's belief that law facilitates communication was grounded in his allegiance to the long and rich Aristotelian tradition of rhetoric. He shared Aristotle's purposive understanding of human action: "Every art and every investigation, and similarly every action and pursuit, is considered to aim at some good..."92 From this basis flowed a commitment to "rhetorical activity" as "a means of discerning and evaluating the ends available to a given community." 93 Chaim Perelman articulated this commitment in philosophical terms by distinguishing between "rational truths" and "reasonable arguments;" the former were meant to be self-evident and compelling, while the latter were convincing reasons for action, but could not cause action. ${ }^{94}$ Rhetorical claims can be persuasive because they are rooted in "prior agreements" or contexts of shared understanding. ${ }^{95}$ On one reading, Fuller's internal morality of the law is an attempt to structure legal processes so that they are most likely to produce rhetorical knowledge, to facilitate interactive communication without pre-supposing specified ends. ${ }^{96}$ When law fulfills the eight criteria of legality it shapes the practical reasoning of citizens and their deliberations about how they should act. ${ }^{97}$ "Rhetoric" captures Fuller's commitment to self-rule through the interaction of government and governed, and to the construction of law through everyday practice by all participants in the system, respecting diverse views as to the definition of the good life. ${ }^{98}$

Bhakshar's structuration theory, which is why Fuller speaks so helpfully to constructivist approaches to international relations. See supra note 43 and accompanying text.

${ }^{91}$ See Adler, Communitarian International Relations, supra note 7 at 15.

${ }^{92}$ Aristotle, supra note 53, I:i, at 63. See also the discussion of "purposive jurisprudence" in Teachout, supra note 53 at $238-45$.

${ }^{93}$ Francis J. Mootz III, "Natural Law and the Cultivation of Legal Rhetoric" in Witteveen \& van der Burg, supra note 50, 425 at 444. See also Lowe, supra note 63 at 221, describing international law as a system "where the plausibility of analogical reasoning and the persuasiveness of topical, rhetorical argument lie at the root of the perception of legitimacy".

${ }^{94}$ Here we are relying on the thoughtful and compelling reading of Perelman by Mootz, supra note 93 at 440-44. For Perelman's philosophy in detail, see Chaim Perelman, The New Rhetoric and the Humanities: Essays on Rhetoric and Its Applications, trans. by W. Kluback (Dordrecht: D. Reidel Publishing Company, 1979); and Chaim Perelman, Logique Juridique (Paris: Dalloz, 1976). Postema and Macdonald also read Fuller as positing that legal rules are reasons, not causes, for human action. See Postema, "Implicit Law", supra note 53 at 262; and Macdonald, supra note 53 at 304. Given Fuller's grounding in Aristotle, this conclusion is completely coherent, for Aristotle emphasized that rhetorical argument could not be as precise as other forms of more "exact" science. Questions of cause and effect had to be evaluated differently in rhetoric (as part of politics) and physical science. Aristotle, supra note 53, I:iii, at 65.

${ }^{95}$ See Adler, Communitarian International Relations, supra note 7 at 15 . Aristotle called these understandings "topics" or "commonplaces," that is accepted frames or starting points for argument. See Aristotle, Rhetoric, trans. by E.S. Forster (Cambridge, MA: Harvard University Press, 1966).

${ }^{96}$ Rhetoric, as a daily practice, "is a continual denial of literalness in meaning and of the reducibility of language to rules." Vining, supra note 51 at 457.

${ }^{97}$ Murphy, supra note 61 at 241.

${ }^{98}$ Willem J. Witteveen, "Rediscovering Fuller: An Introduction" in Witteveen \& van der Burg, supra note 50, 21 at 37. As we will illustrate in Chapter 3, this practice-driven account of the generation of law is, of course, closely allied to Adler's "community of practice" description of the generation of all social norms. 
At this point in the argument, now that questions of Fuller's moral characterization of law have been addressed, we return to the congruence of legal norms with social practice. ${ }^{99}$ We must reiterate that "social practice", or in constructivist terms "shared understandings," need not be (in fact rarely are) deep moral commitments. It is possible to imagine law rooted in thin shared moral commitments, such as autonomy and communication. For example, basic rules of contract law may be grounded in notions of free consent (autonomy) and transaction (a blending of material and psychic forms of communication). However, as societies attempt to articulate more ambitious rules related to human interaction, such as anti-discrimination statutes or surrogate mother contracts, we find that substantive moral commitments are expressed in law. To be effective, ambitious substantive norms require deeper shared understandings of the right ordering of society. There is no possibility of simply imposing significant social change by fiat in the absence of some degree of social consensus, expressed in practice.

We are not suggesting that there is no "educative value" in law, only that any such value is but a starting point for the hard work of norm entrepreneurs. As we have already argued, the form of law alone is not enough to generate behavioural change. Nor does our argument imply that we must simply defer to existing practice; it is possible - our point is that it is necessary - to work to construct shared understandings. ${ }^{100}$ In summary, law is rooted in social practice that generates shared understandings, and we can work to make these shared understandings deeper through more and more interaction. This can, but will not necessarily, lead to law that is more ambitious, that regulates more intrusively. Merely declaring the form of "law" alone will not accomplish this end, a point to which we return towards the end of this chapter.

Fuller's legal theory, as should be obvious from this brief tour d'horizon, is not instrumental, in the sense that he never seemed to be setting up arguments simply to further a particular moral or political agenda, ${ }^{101}$ with the exception of his weak liberal commitment to human autonomy matched with the human need to communicate. As we have suggested, what enables interactional law to promote autonomy is that it is independent of stronger moral or political commitments. That, in turn, enables it to facilitate communication and to protect diversity, one of its strengths in conceptualizing the role of law in international society. ${ }^{102}$

\section{Fuller and International Law}

\footnotetext{
99 See supra note 64 and accompanying text on Postema's "congruence thesis." It is important to distinguish Postema's concept of congruence between law and wider social practice from Fuller's emphasis on the need for congruence between official action and the law. The two ideas are of course interrelated. But, whereas Fuller's notion of congruence is one of the requirements of legality he posited, Postema's congruence thesis is concerned with the pre-conditions that must exist for legality to evolve.

${ }^{100}$ See also Adler, Communitarian International Relations, supra note 7 at 12 (stressing that "constructivism takes a dynamic view of social life in which new practices, identities, and interests emerge with new constitutive rules and newly evolving social structures.")

${ }^{101}$ But see supra note 85 (concerns raised, e.g., by Westerman and Schauer).

${ }^{102}$ See infra note 135 and accompanying text.
} 
Fuller wrote primarily with domestic law in mind, ${ }^{103}$ and his principal area of interest was property and contract theory, but his fundamental preoccupation was with law as a set of non-hierarchical practices ordering human interaction. To that extent, he speaks directly to the parallel preoccupations of international legal theorists, all of whom inevitably struggle to understand how norms function in the horizontal normative order that is international society. Fuller helps us to understand five key points. First, that domestic law is also "horizontal" in important ways; indeed horizontality is an asset for, not a defect of, law. Second, that appreciating law's grounding in social interaction reveals the real locus of its power to shape human behaviour, through the generation of fidelity, a sense of obligation, rather than through rationalist accounts of reciprocal advantage. Third, that a thin, largely procedural, conception of the rule of law upholds and supports diversity in moral and political ends while at the same time helping to build a stronger global society, perhaps with pockets of deeper normative communities. Fourth, international lawyers rely too heavily upon state-centric, hierarchical accounts of legality. Fifth, "legitimacy" can have a specific, legal meaning. Additionally, we suggest that Fuller's theories, when linked to constructivist insights from IR, help to better explain the contemporary practice of international law.

First, in addressing the horizontal nature of law, it bears repeating that within all systems of legal normativity, even state systems of law, social norms are constructed through rhetorical activity and social practice producing increasingly influential mutual expectations or shared understandings of actors. In turn, if these shared understandings are reinforced through action based upon Fuller's criteria of legality, it becomes possible to generate obligation, or fidelity to law. The interactional view, in which agents participate actively in the construction of law, helps make sense of central features of the international legal system, for example Georges Scelle's "dédoublement fonctionnel,"104 the idea that states are both subject to and sovereign in international law, that cannot be comfortably accommodated within theories of law predicated upon hierarchical projections of authority. The parallel to Fuller's commitment to autonomy in the domestic sphere is the traditional commitment in international society to sovereignty. But this observation requires some nuance.

There is an important difference between human agency in Fuller's interactional law and state sovereignty in interactional international law. Human agency is central to Fuller's

\footnotetext{
${ }^{103}$ Fuller did not apply his insights to the realm of international law in any sustained way. Indeed, in one of his brief references, he seemed to deny that international society could aspire to a rule of law. See Lon L. Fuller, "The Forms and Limits of Adjudication" in Winston, supra note 60, 86 at 102 . We think that he was wrong, and that he missed opportunities in international society both to apply and to find support for his own insights. It may be that Fuller's thinking was so much shaped by the Cold War that he could not imagine the purposes of international law beyond "preventing a holocaust". For a brief, but more engaged, discussion of international law and its relationship to his own theoretical approaches, see Fuller, Morality of Law, supra note 1 at 232-33 and 236-37.

${ }^{104}$ See Georges Scelle, "Le Phénomène Juridique de Dédoublement Fonctionnel” in Walter Schätzel \& Hans-Jürgen Schlochauer, eds., Rechtsfragen der internationalen Organisation: Festschrift für Hans Wehberg zu seinem 70. Geburtstag (Frankfurt: Klostermann, 1956) 324 (Scelle highlighted the dual role of states as both subjects of international law and lawmakers).
} 
account in that autonomy is at once the basis of interactional law and in part, along with the possibility of communication, what it is meant to protect. Thus, while individuals' decisions may be guided by law and their social identities are shaped by interaction through law, their socially constructed autonomy is the prerequisite for interactional law. By contrast, sovereign states are but an imperfect proxy for human agency. It is nonetheless possible to think of states' interaction through law as comparable to that of individual human beings. ${ }^{105}$ After all, states are collective entities constituted and represented by people. For that reason, it does make analytical sense to speak of states as individual agents, and to treat sovereignty as a proxy for autonomy. Similarly, constructivists are right to base their analysis of international relations on the proposition that states' have "identities" and that their identities and actions are shaped in part by social interaction, including interaction through law. ${ }^{106}$

Yet, none of this means that state sovereignty is indispensable for interactional international law in the same way that human agency is for Fuller's theory. Rather, in the case of states, it is international law that constitutes their autonomy in the first place, by defining what sovereignty means at any given point, or what attributes make a collective entity a "state." An individual human being exists outside law, though his or her ability to act in society may be strongly affected by law. A "state" only exists within a normative framework, in our era, the framework of international law. In other words, unlike individual human beings, states are entirely creatures of interaction. States are but one manner in which people can organize themselves to pursue their goals. Obviously, in contemporary international society, states remain the dominant players, often even at the expense of individuals' autonomy. But the increasing participation of individuals and non-state collectivities, such as governmental or non-governmental organizations or corporations, is indicative of the potential for major shifts in the breadth of international legal interaction. At the same time, the interactional perspective helps us to make sense of existing patterns of participation in international lawmaking where norms, although formally sanctioned by states alone, are in fact influenced strongly by a diversity of actors. $^{107}$

Turning, secondly, to the creation of obligation, we note that rationalists in IR and positivists in international law also describe interactional processes, and they typically rely on "reciprocity" as the explanation for law. But for rationalists and positivists, reciprocity is simply a series of transactions in which interests are traded for advantages. Law enables the efficient functioning of society by sending coherent signals that make interaction predictable. Participation in such a system is rational because an individual

\footnotetext{
${ }^{105}$ Gerald J. Postema, "Custom in International Law: A Normative Practice Account" in Amanda PerreauSaussine \& James Bernard Murphy, eds., The Nature of Customary Law: Legal, Historical and Philosophical Perspectives (Cambridge, MA: Cambridge University Press, 2007) 279 at 306 (arguing that, "[d] espite obvious disanalogies, international actors, like individual human agents, can and do engage in discursive, practically concrete normative practices.").

${ }^{106}$ For a detailed discussion, see Trine Flockhart, “'Complex Socialization': A Framework for the Study of State Socialization" (2006) 12 European Journal of International Relations 89.

${ }^{107}$ But see Kingsbury, supra note 10. He argues that "publicness" comes from both who entities are (public entities) and what they do, whereas we suggest that it is the practice, the doing, which counts, not formal status. So non-state actors come to have an important role in the generation of transactional law.
} 
agent is benefited by both the possibility of exchange in material interests and predictability in relationships. The paradigmatic example for rationalist-positivists is trade agreements. ${ }^{108}$ To the extent that rationalist-positivists would acknowledge any binding effect of law, it is rooted in a form of reciprocity that ensures that the constraint imposed on one is imposed on all. The system is stable because of the implied threat that if one agent "defects," others will as well. ${ }^{109}$ The rationalist version of reciprocity is helpful in understanding how interests affect norms and behaviour. But it does not go far enough. As we have argued above, "interests" come from somewhere, and are not created solely by rational assessments of material conditions. Interests are rooted in identity and identity is formed in large measure through social interaction.

Still, reciprocity in the rationalist sense just described is the most common explanation given by international lawyers for the existence of legal norms. Following on from the New Haven School, Rosalyn Higgins argued that there is no point in searching for an explanation of obligation. In her view, international law functions purely on the basis of reciprocal obligations rooted in interests. ${ }^{110}$ Other legal theorists look to a type of systemic reciprocity explained by the long term interests of states in the predictability provided by law. ${ }^{111}$

For Fuller, and for us, reciprocity is deeper than the exchange flowing from the calculation of material interests, or the direction inherent in what he called "managerial control."112 Fidelity to law depends upon the reciprocal fulfilment of duties. ${ }^{113}$

\footnotetext{
${ }^{108}$ See, e.g., Beth Simmons, "The Legalization of International Monetary Affairs" (2000) 54 International Organization 573; and Beth Simmons \& Daniel Hopkins, "The Constraining Power of International Treaties" (2005) 99 American Political Science Review 623.

${ }^{109}$ See, e.g., Robert Axelrod, The Evolution of Cooperation (New York: Basic Books, 1984); Robert O. Keohane, "Reciprocity in International Relations" (1986) 40 International Organization 1; George W. Downs, David M. Rocke, \& Peter N. Barsoom, "Is the Good News About Compliance Good News About Cooperation?" (1996) 50:3 International Organization 379. But see also Fearon \& Wendt, supra note 27 at 61 (suggesting that this type of reciprocity may also have a normative dimension: fairness).

${ }^{110}$ Rosalyn Higgins, Problems and Process: International Law and How We Use It (Oxford: Clarendon Press, 1994) at 16. See also Michael Byers, Custom, Power and the Power of Rules (Cambridge: Cambridge University Press, 1999) at 89-105; Goldsmith \& Posner, supra note 22 at 7 and 13. See also Chapter 3.

${ }^{111}$ See Louis Henkin, How Nations Behave: Law and Foreign Policy, 2nd ed. (New York: Columbia University Press, 1979) at 51-52; Abram Chayes \& Antonia Handler Chayes, The New Sovereignty: Compliance with International Regulatory Agreements (Cambridge, MA: Harvard University Press, 1995) at 26-27; J.L. Brierly, The Law of Nations: An Introduction to the International Law of Peace, ed. by Humphrey Waldock (Oxford: Clarendon Press, 1963) at 55-56.

${ }^{112}$ See Fuller, Morality of Law, supra note 1 at 203-4 and 214 (suggesting that positivists' claims re "efficacy" rather than morality stem from assumptions grounded in "managerial control" (= rationalism) rather than law). It is ironic that in criticism of our earlier work, we have been associated with "managerialist" compliance theorists such as Chayes \& Chayes, ibid. Although we do agree with the Chayes' when they highlight the importance of interactional, justificatory processes, we do not share their rationalist explanation of why actors adjust their behaviour in interaction. For a full discussion, see Chapter 3 and Jutta Brunnée \& Stephen J. Toope, "Persuasion and Enforcement: Explaining Compliance with International Law” (2002) 13 Finnish Yearbook.of International Law 273.
} 
Lawmakers must adhere to the criteria of legality because, as we suggested above, in so doing they give citizens the opportunity to reason with rules. If the criteria of legality are neglected, these norms will have failed to become law and citizens will feel resentment; they will have no desire to abide by the promulgated norms. Reciprocity will fail. In addition, "the existence of duties depends partly on the behavior of others." Why should a person feel obliged to act in certain ways if no similar expectations apply with respect to those judging that person's behaviour? ${ }^{114}$

This analysis resonates strongly with the "logic of appropriateness" articulated by two sociologists of organization, James March and Johan Olsen. ${ }^{115}$ Their influential work has demonstrated that decisions are grounded in two different "logics." 116 The first, the logic of consequences, is related to rationalist-positivist reciprocity. On this logic, decisions are purely instrumental: "How do I get what I want, and what will happen if I behave in a certain way?" The second, the logic of appropriateness, focuses upon social norms, and paves the way towards a theory of legal obligation. This logic engenders self-reflection, prompting the central question "What should I do in this situation?",117

March and Olsen help us appreciate that the decisions of actors can be motivated both by consequentialist concerns and moral considerations. ${ }^{118}$ So reciprocity is not limited to material exchange, but can also be grounded in the desire to interact, to create sustained relationships. ${ }^{119}$ Our reading of Fuller shows how, in law, the logic of appropriateness can develop into a sense of legal obligation. ${ }^{120}$

113 Thus, for Fuller, "reciprocity" was the connection between citizens and government with respect to the observance of rules. This version of reciprocity is captured especially in Fuller's eighth criterion of legality. See Waldron, supra note 51 at 277.

${ }^{114}$ Murphy, supra note 61 at 242.

${ }^{115}$ See James G. March \& Johan P. Olsen, Rediscovering Institutions (New York: Free Press, 1989) [March \& Olsen, Rediscovering Institutions].

${ }^{116}$ March and Olsen's initial work was focused upon democratic politics at the national level. See March \& Olsen, ibid.; and James G. March \& Johan P. Olsen, Democratic Governance (New York: Free Press, 1995). They subsequently applied it to international political relations. See James G. March \& Johan P. Olsen, "The Institutional Dynamics of International Political Orders" (1998) 52 International Organization 943 [March \& Olsen, "International Political Orders"].

${ }^{117}$ March \& Olsen, Rediscovering Institutions, supra note 115. See also Finnemore \& Sikkink, supra note 12 at 914.

${ }^{118}$ See March \& Olsen, "International Political Orders", supra note 116 at 952; and Fearon \& Wendt, supra note 27 at 60. See also Harald Müller, "Arguing, Bargaining and All That: Communicative Action, Rationalist Theory and the Logic of Appropriateness in International Relations" (2004) 10 European Journal of International Relations 395 at 400-401.

${ }^{119}$ Note that, in any event, the very "capacity for rational thought and behavior is not only an individual, but also and above all a [social] capacity... Rationality lies less in the act of instrumental choice between alternatives on the basis of true theories than in behaving in ways that stand to reason, given people's background expectations and dispositions." See Adler, "Constructivism in International Relations", supra note 30 at 103. In short, constructivists "consider rationality and reason to be of critical importance," but they do not accept "the notion that rationality means only instrumental rationality." Adler, ibid., at 102.

${ }^{120}$ For March \& Olsen, supra note 115 [?] at 23 and 59, the logic of appropriateness entails "duties" and "obligations" to act. Our work suggests why a particular type of "logic of appropriateness" is engaged by legal obligation. 
In international society, the deeper sense of reciprocity is even more salient because states are both subjects and lawmakers. To the extent that international law is created without adhering to congruence with shared understandings and Fuller's criteria of legality, fidelity to law - the sense of obligation - amongst states will not be generated. ${ }^{121}$ The central insight is that the kind of reciprocity that we are speaking of is not about "titfor-tat" interactions between individual actors. Rather, reciprocity is created and maintained collectively. To be sure, not all members of international society must be engaged in this enterprise. Interactional law can withstand individual defiance so long as a majority of actors works to uphold legality. Yet, the fact that reciprocity requires collective effort also serves to underscore why claims to legal "exceptionalism" by powerful states can be so corrosive. Some states will be actively resentful when confronted with such claims, or with other failures to meet the requirements of legality.

This way of addressing reciprocity explains why it is that the governments of so many developing states express frustration, even anger, over the evolution of international law. Our point is that this resentment cannot be ascribed purely to moral differences as to the proper ends of law, to "politics." They arise because of failures in the very creation of law, failures that in too many cases render international law illegitimate. The formation of a simple treaty provides a useful illustration. If the imbalance of power between the parties is great, if there is no real opportunity for negotiations, and if no mutual sense of duty is evident, then states really have not created a treaty at all, but have merely acted in the form of treaty. ${ }^{122}$ For example, the sense of hypocrisy which can generate illegitimacy is apparent in the entire nuclear non-proliferation regime, where the main nuclear powers have failed to discharge their obligation to seriously pursue nuclear disarmament. $^{123}$

Fuller's fidelity argument may seem to relate closely to conceptions of signalling in rationalist IR theory, or to the indicators of "obligation, precision and delegation" posited by rationalist IR and international law scholars for the purposes of interdisciplinary study

\footnotetext{
${ }^{121}$ For a discussion of how ideas conceived in the context of individual persons may nonetheless apply to entities like states, see supra note 97 and accompanying text, and Chapter 3. Briefly put, state governments are made of up of individual decision makers who are capable of belief and who can experience a sense of obligation. But see Goldsmith \& Posner, supra note 22 at 15 (suggesting that there is no evidence that "states are pulled to comply with international law because it reflects morally valid procedures, or consent, or internal value sets..."), and at 185-202.

${ }^{122}$ Gerry Simpson offers the Ottoman capitulations and the Treaty of Nanking of 1842 as two, particularly influential, examples of such treaties. See Great Powers and Outlaw States: Unequal Sovereigns in the International Legal Order (Cambridge: Cambridge University Press, 2004) at 243, n. 61. Note that in this description, the "form" of treaty is parallel to the form of "contract" described in the text following note 69. We are offering an illustration parallel to our earlier discussion of invalid contracts. See supra, text accompanying note 69 . However, we are not suggesting that treaties should be seen in purely contractual terms.

${ }^{123}$ For an analysis of the way in which US administrations have sought to avoid the Nuclear NonProliferation Treaty's original goal of disarmament while pressing for increasingly stringent counterproliferation measures, see Richard Price, "Nuclear Weapons Don't Kill People, Rogues Do" (2007) 44:2/3 International Politics 232.
} 
of "legalization." 124 It could be suggested that all that the criteria of legality do is to get the signalling right so that agents know how they should behave. ${ }^{125}$ That would be like saying that law is the same as a set of signs in an airport: if they are coherent, clear, notcontradictory, etc., the passengers will find their planes. But this is too limited an understanding of Fuller's criteria of legality: they are not merely signals but are conditions for the existence of law. Only when the conditions of legality are met, and embraced by a community of practice, can we imagine agents feeling obliged to shape their behaviour in the light of the promulgated rules. ${ }^{126}$ The criteria of legality are directed to the creation of obligation, and obligation is the "value added" of law, distinguishing it from social desiderata, airport signs, or the rationalist proposition that "obligation" is a mode of action chosen by actors to signal credible commitment. ${ }^{127}$

Third, Fuller's thin conception of the rule of law is particularly useful in global society. ${ }^{128}$ It is congenial to diversity, but permits and encourages the gradual building up of global interaction. An interactional view of law would suggest that law is only possible within specific times and places where actors have developed certain basic understandings about what they hope to achieve together. They need not agree on a definition of the good life, only on basic objectives. Actors bring their cultural specificity to the table, as it were, but accept that they will not convince other actors of the desirability of a particular worldview. However, if there is no agreement on even the parameters of coordinated social action, legal normativity cannot emerge. Basic understandings can, however, be

\footnotetext{
${ }^{124}$ On "signaling" in rationalist IR theory, see Simmons, supra note 108. The rationalist idea that actors choose legal form to "signal" "credible commitment" also underpins the "legalization" project, and is reflected in the indicator of "obligation." Kenneth W. Abbott \& Duncan Snidal, "Hard and Soft Law in International Governance” (2000) 54 International Organization 421, at 426-430. See also Abbott et al., supra note 25 at $408-412$.

${ }^{125}$ [So rationalists in IR are linked directly to Raz and Hart's point as well. Add Posner ??.]

${ }^{126}$ This does not mean "that each law must be regarded as having moral force on its own." Actors "may well follow a particular law out of calculated self-interest or to avoid governmental coercion." Winston, supra note 50 at 62 . Our point is a broader point about fidelity to the legal order.

${ }^{127}$ Notably, the "legalization" project brackets the question how obligation is explained and employs it as an indicator of commitment. See Abbott et al., supra note 25 at 401 (observing that "[o]bligation means that states or other actors are ... legally bound by a rule or commitment in the sense that their behavior thereunder is subject to scrutiny under the general rules, procedures, and discourse of international law, and often of domestic law s well "). Our point is that it is precisely obligation that must be generated in the first place, so that the legalization project is weakened by a significant blind spot. See also discussion in Jutta Brunnée, "Review: Legalization and World Politics. Edited by Judith L. Goldstein, Miles Kahler, Robert O. Keohane, \& Anne-Marie Slaughter (2001)" (2003) 1 Perspectives in Politics 231; Martha Finnemore \& Stephen J. Toope, “Alternatives to 'Legalization': Richer Views of Law and Politics” (2001) 55 International Organization 743.

${ }^{128}$ See also Nardin, supra note 48 at 24-25 (arguing that "where the rule of law is the mode of association, they are rules of a certain kind. They are noninstrumental rules. A noninstrumental rule is concerned solely with the propriety of actions, not their usefulness in achieving or avoiding certain outcomes.") and at 28 (suggesting that this conception is essential for law in international society, since it avoids "the extremes of Hobbesian positivism, which makes legality itself the criterion of justice, and natural law, which makes justice into a criterion of legality."). Fuller's understanding of the rule of law is also close to that articulated by Tamanaha. See Brian Z. Tamanaha, On the Rule of Law (Cambridge: Cambridge University Press, 2004) at 94 ("The fact that this version of the rule of law has no content requirements renders it open to a range of ends. ... This substantively empty quality has been identified by theorists, and by the World Bank and other development agencies, as what renders it amenable to universal application.")
} 
fostered through pre-legal mutual interaction in informal and formal institutions, through the work of norm entrepreneurs, through the engagement of epistemic communities and issue networks, and through other processes of socialization affecting the self-perception and identity of actors. ${ }^{129}$

The criteria of legality within Fuller's conception of the rule of law enable states to "reason" from law to achieve their own objectives, thereby preserving diversity. But Fuller's essentially communicative understanding of law, rooted in the Aristotelian rhetorical tradition, means that it is in the very process of interaction - of reasoning through law - that one can achieve a modest and gradual building-up of society. ${ }^{130}$ Fuller did, however, aspire to more: as humans, and we would add states and other international actors, communicate through law, opportunities arise to deepen shared understandings. Around certain concrete issues, for example an environmental problem or a human rights concern, it may even be possible to cultivate normative convergence. Fuller was not naïve. He never posited an existing global moral community. ${ }^{131}$ Though not a moral relativist, ${ }^{132}$ Fuller insisted that cultural specificity is relevant to any definition of "community". 133 But he nonetheless concluded that "we should aspire to enlarge that community at every opportunity and to include within it ultimately, if we can" all people of good will. ${ }^{134}$

Our point is that although building shared understandings is a goal, with Fuller one must always remember that the enterprise of lawmaking he described is aspirational. He wanted to challenge societies to work towards the goal of fidelity to law but he never

\footnotetext{
${ }^{129}$ See our discussion of the importance of pre-legal normativity and the evolution of "contextual regimes" in Brunnée \& Toope, "Environmental Security," supra note 56.

${ }^{130}$ This idea also is central to constructivist work, which emphasizes the intersubjective nature of societies and communities. See supra notes 45-46 and accompanying text.

${ }^{131}$ Fuller did not insist on the necessity of "broad agreement on general values" even within specific legal cultures, only shared standards by which disagreements could be identified and discussed meaningfully toward some rational resolution. Postema, "Implicit Law", supra note 53 at 269. The rejection of a universal definition of the Good (apart from a broadly defined individual happiness) is derived from Aristotle. See supra note 53, I:vi, at 69, and I:vii, at 73.

${ }^{132}$ Mootz, supra note 93 at 450.

${ }^{133}$ Because of Fuller's sensitivity to local culture, he never succumbed to the liberal triumphalism often displayed in Western (and particularly U.S.) legal theory. See Lon L. Fuller, “The Law's Precarious Hold on Life" (1969) 3 Georgia Law Review 530, discussing law in the processes of African decolonization. See also Dyzenhaus, supra note 69 at 90 and 96-97. Indeed, even a relatively unsympathetic reader is able to enlist Fuller "into the enterprise of deflating the celebratory posture toward law, legal institutions, and legal actors that pervades so much of American legal thought". Frederick Schauer, "Fuller on the Ontological Status of Law" in Witteveen \& van der Burg, supra note 50, 124 at 142.

${ }^{134}$ Fuller, Morality of Law, supra note 1 at 183. Almost exactly the same formulation of human aspiration is offered, within secular, pragmatist philosophy by Richard Rorty, Contingency, Irony, and Solidarity (Cambridge: Cambridge University Press, 1989) 196 (while treating the notion of common humanity as nothing more than a useful focus imaginarius, it "is a means of reminding ourselves to keep trying to expand our sense of 'us' as far as we can.”).
} 
assumed that the goal would be fully achieved. ${ }^{135}$ It is not necessary to have a morally cohesive "community" before lawmaking is possible. In this sense, Fuller's theory differs from Habermas's concept of communicative action, where it would seem that a "common lifeworld" is a precondition to effective norm building. ${ }^{136}$ Nor is our interactional view of international law predicated upon a vision of a growing liberal world community. Our theory of legal obligation is not aligned with cosmopolitan liberalism, ${ }^{137}$ or with theories of the "democratic peace," constitutionalism. ${ }^{139}$ Rather, we envisage interactional law as a particular kind of "community of practice," a concept that we will explore in more detail in Chapter 2. We reiterate Adler's important observations that the "joint enterprise of members of a community of practice does not necessarily mean a common goal or vision," but that members "must share collective understandings that tell [them] what they are doing and why," which have obvious resonance with the concept of law that we have developed in this chapter. ${ }^{140}$

We have already noted that an interactional theory of law opens up lawmaking to a diversity of participants, indeed requires it, because of the need for reciprocity in the construction of law. It follows that any description of society at the international level

\footnotetext{
${ }^{135}$ So much so that he would argue that "the inner morality of law is condemned to remain largely a morality of aspiration and not of duty. Its primary appeal must be to a sense of trusteeship and to the pride of the craftsman." See Fuller, Morality of Law, supra note 1 at 43.

${ }^{136}$ Habermas's lifeworld appears to consist in common cultural and historical traditions, shared norms and socialized participants. See, e.g., Jürgen Habermas, Between Facts and Norms: Contributions to a Discourse Theory of Law and Democracy (Cambridge, MA: MIT Press, 1996) at 80. But Habermas, ibid., at 22, also appears to contemplate that communicative action can build sufficient commonality: "The lifeworld forms both the horizon for speech situations and the source of interpretations, while in turn it produces itself only through ongoing communication." According to Thomas Risse, "'Let's Argue!': Communicative Action in World Politics" (2000) 54:1International Organization 1 at 14, "Habermas's theory is rather silent on the question of how much of a common lifeworld people need to share in order to communicate in a reasonable manner."

${ }^{137}$ See, e.g., Bruce Russett, Grasping the Democratic Peace: Principles for a Post-Cold War World (Princeton, NJ: Princeton University Press, 1993); Thomas Risse-Kappen, Cooperation Among Democracies: The European Influence on US Foreign Policy (Princeton, NJ: Princeton University Press, 1995); John Rawls, The Law of Peoples; with "The Idea of Public Reason Revisited" (Cambridge, MA: Harvard University Press, 1999); and Allen Buchanan \& Robert O. Keohane, "The Legitimacy of Global Governance Institutions" (2006) 20:4 Ethics and International Affairs 405.

${ }^{138}$ For various accounts, some more sympathetic than others, see Thomas Franck, "The Emerging Right to Democratic Governance" (1992) 86 American Journal of International Law 46; Anne-Marie Slaughter, "Building Global Democracy" (2000) 1 Chicago Journal of International Law 223; and Gregory H. Fox \& Brad R. Roth, eds., Democratic Governance and International Law (Cambridge: Cambridge University Press, 2000).

${ }^{139}$ There are many versions of global constitutionalism. See, e.g., discussions in Matthias Kumm, "The Legitimacy of International Law: A Constitutionalist Framework of Analysis" (2004) 15 European Journal of International Law 907; Erika de Wet, “The International Constitutional Order” (2006) 55 International and Comparative Law Quarterly 51; and, for a critical perspective, Jeffrey L. Dunoff, "Constitutional Conceits: The WTO's 'Constitution' and the Discipline of International Law” (2006) 17 European Journal of International Law 647.

${ }^{140}$ Adler, Communitarian International Relations, supra note 7 at 22 . And supra note 30 and accompanying text.
} 
must extend beyond the sphere of states. ${ }^{141}$ International organizations, NGOs, corporations, informal intergovernmental expert networks, and a variety of other groups are actively engaged in the creation of shared understandings and the promotion of learning amongst states and other international actors. As we have already emphasized, although states remain dominant within the system, they are influenced (admittedly in different ways and to different extents) by the persuasive activities of less obviously powerful actors. The differential impact of such persuasive efforts is partly dependent upon politics within states, which remains an important focus of attention for norminterested IR scholars and international lawyers alike. ${ }^{142}$

The fourth lesson for international law derived from Fuller's theories is that international lawyers rely too heavily on positivist accounts of legality. ${ }^{143}$ Positivism does not provide an accurate account of legal obligation. Nor does it fully explain how law operates within international society. As to the operation of law, Fuller's central argument is that law does not depend upon enforcement for its existence, much less on the use of physical force, though power and force are relevant in understanding human interaction in law as elsewhere. This insight is fundamental for international lawyers who are constantly challenged to show how a rule that is not backed by a sanction can be law. Like Fuller, we accept that power and force are salient to law, but they do not explain the sense of obligation that must exist in international society for legal enforcement to be possible and effective. We distinguish between raw power and legal authority.

It is nonetheless important to recognize that a failure to enforce does tend to undermine fidelity to law, not because of the need for external validation through "force," but because laws that are "kept on the books as a kind of symbolic act, with the knowledge that they will not and cannot be enforced" lead to a sense of hypocrisy that damages any commitment to the rule of law. ${ }^{144}$ Fuller's understanding of the failure to enforce norms helps us appreciate why it is that so many people are frustrated by international law: it is not because law requires enforcement to be law, but because law requires fidelity. That fidelity is damaged when law is seen to have no possibility of effect. This is the lesson of Fuller's eighth criterion of legality: congruence between law and official action or, in the case of international law, congruence amongst the actions of a majority of international actors. When explicit rules are unrelated to how states and other international actors actually behave, fidelity is destroyed. ${ }^{145}$

\footnotetext{
${ }^{141}$ See also Michael Walzer, Spheres of Justice: A Defense of Pluralism and Equality (New York: Basic Books, 1983) (on overlapping norm systems).

${ }^{142}$ See, e.g., Harold Hongju Koh's discussion of transnational legal process in "Transnational Legal Process" (1996) 75 Nebraska Law Review 181at 199-205; Eyal Benevenisti, "Domestic Politics and International Resources: What Role for International Law?" in Byers, supra note 19, 109; and Katzenstein, Keohane \& Krasner, supra note 21 at 663-70. The widely debated "democratic peace" literature is founded upon the belief that the primary causal explanation for respect for international norms is internal democratic processes of liberal societies. See, e.g., Russett, supra note 137; Risse-Kappen, supra note 137; and the recent recasting of John Rawls' theory of justice in an international context: supra note 137, at 44-54.

${ }^{143}$ See also discussion in Dyzenhaus, supra note 69, 78.

${ }^{144}$ Fuller, Morality of Law, supra note 1 at 153.

${ }^{145}$ See also supra notes 98 and 128-129 and accompanying text.
} 
We have previously noted that Fuller was not particularly interested in the distinction between legal and other social norms. On this point we differ and share one of positivism's goals: to distinguish between what is legally required and what is desirable or acceptable. We suggest that this distinction is not based in any particular form of rule, but in a sense of obligation generated by fidelity to law. Our concern is that legal formalism pervades the practice of international law today - hence the exclusive reliance on sources of law as a means to define the existence of binding rules, the assumption that decisions of the International Court of Justice apply only "positive" law derived from the consent of states, and the desire to define a bright line boundary between law and nonlaw. We argue that great caution is required in trying to trace out the law and non-law distinction. Legal formalism is inadequate to the task.

The key is to distinguish between "formality" and "formalism". Formality is actually an aspect of Fuller's internal criteria of legality: it includes ideas such as promulgation and publicity, and not asking the impossible. ${ }^{146}$ Nonetheless, thinking about the creation of law in purely formal terms provides only limited guidance in analysing how obligation is created in international society. Although formal indicators provide useful indicia of the existence of binding rulesand, of course, "validity" on the terms of the system, they are not enough to identify "law" because formality alone is not strong enough to generate fidelity. What is more, the move from formality to formalism can actually mask the absence of any real sense of obligation.

By formalism, we mean a view that treats form as the only indicator of law, and which is close to legalism as described by Judith Shklar. ${ }^{147}$ For example, when diplomats return to their capitals after "successfully" concluding a treaty, we argue that the hard work of international law has often just begun. We must assess whether the conditions for the creation of obligation - the existence of shared understandings, and the eight criteria of legality - have been met. First, is the treaty rooted in shared understandings reflecting some social consensus that the goals of the treaty are desirable? Alternatively, is it possible to use the treaty as an educative device to work towards shared understandings that can support the transformation of treaty language into real legal obligations? Second, does the treaty meet the criteria of legality? Was it concluded through processes that allowed for the genuine participation of relevant actors? Is the language clear enough to be understood in commensurable ways by members of the treaty regime? Does the treaty contradict other international law obligations, or ask the impossible of states? Eventually, one must also ask whether or not the treaty gives rise to a practice of legality and actually comes to shape the actions of parties. If it does not do so in a relatively widespread manner, then an individual state party is likely to conclude that

\footnotetext{
${ }^{146}$ See Waldron, supra note 51 at 276: "One way of looking at Fuller's jurisprudence is that he is asking whether there is anything in the formal character of law that can possibly sustain this fidelity, any source of respect inherent in legality as such which may survive a loss of faith in substantive ends which the government is pursuing."). See also Stephen J. Toope, "Formality and Informality" in Daniel Bodansky, Jutta Brunnée \& Ellen Hey, eds., Oxford Handbook on International Environmental Law (Oxford: Oxford University Press, 2007) 107.

${ }^{147}$ Judith Shklar, Legalism: Law, Morals, and Political Trials (Cambridge, MA.: Harvard University Press, 1986).
} 
there is no congruence between the requirements of the treaty and the application of the treaty. The treaty will be ignored because it will have inspired no "fidelity".

To be clear, given the very real practical challenge of capturing and communicating shared understandings in the international setting, the treaty will often be an important step in interactional lawmaking. After all, the number of actors in the international arena is so large and their opportunities for direct interaction are so limited that "snap shots" of the common ground will often be needed to advance the lawmaking process. Both treaties and customary international law can provide these snap shots. But the interactional account instructs that it is crucial not to mistake the formal representation of law for successful law-making.

International lawyers also regularly grapple with a phenomenon called "soft law." Some commentators insist that the term is nonsensical or even dangerous. ${ }^{148}$ Others would accept that soft law is a relevant category, and matters in some way, but they cannot fit soft law's effects within formal sources doctrine. ${ }^{149}$ We argue that "soft" norms may sometimes possess more obligatory force than norms derived from formal sources of law. Interactional international law explains why. When norms are rooted in shared understandings and adhere to the conditions of legality, they generate fidelity. Christine Chinkin makes a similar point in reverse:

While soft law may not be directly used to found a cause of action it has both a legitimising and a delegitimising direct effect: it is extremely difficult for a State that rejected some instrument of soft law to argue that behaviour in conformity with it by those who accepted it is illegitimate. ${ }^{150}$

In other words, it is hard to attack the fidelity produced through interactional lawmaking. Although at first blush soft norms do not figure in the "causes of action" allowed in adjudicative international decision making for they do not fit within Article 38 of the ICJ Statute, such norms can figure in practical legal reasoning of courts, states and other international actors. For example, the precautionary principle is not universally accepted as a norm of customary law, but it has influenced the decisions of international tribunals, ${ }^{151}$ framed international treaties ${ }^{152}$ and been embraced at the domestic level. ${ }^{153}$

\footnotetext{
${ }^{148}$ See, e.g., Jan Klabbers, “The Redundancy of Soft Law” (1996) 65 Nordic Journal of International Law 167; Prosper Weil, “Towards Relative Normativity in International Law?” (1983) 77 American Journal of International Law 413.

${ }^{149}$ See, e.g., Pierre-Marie Dupuy, "Soft Law and the International Law of the Environment" (1991) 12 Michigan Journal of International Law 420.

${ }^{150}$ Christine Chinkin, “The Challenge of Soft Law: Development and Change in International Law" (1989) 38 International and Comparative Law Quarterly 850 at 850-1.

${ }^{151}$ Gabčíkovo-Nagymaros Project (Hungary/Slovakia), Judgment, I.C.J. Reports 1997, 7. For information on the activities of the Commission for the Conservation of Southern Bluefin Tuna, see online at: http://www.ccsbt.org/ (last accessed on February 12 2008).

${ }^{152}$ Cartagena Protocol on Biosafety to the Convention on Biological Diversity: Text and Annexes (Montreal: Secretariat of the Convention on Biological Diversity, 2000).

${ }^{153}$ See the Preamble to the Canadian Environmental Protection Act, S.C. 1999, c. 33.
} 
To summarize, it is crucial to distinguish Fuller's largely procedural, and hence relatively "thin," conception of the rule of law from "formalism." While we are sympathetic to his underlying preoccupations, we are not convinced by Martti Koskenniemi's advocacy of a "culture of formalism" - the idea that only rigorous insistence upon the "validity" of rules - measured by the consent of sovereign states - can serve as a bulwark against the domination of world society by Great Powers, especially by the single superpower. ${ }^{154}$ The notion of a "culture" of formalism is intended to highlight the only way for international law to protect global diversity and resist political hegemony: by providing a "shared surface ... on which political adversaries recognize each other as such and pursue their adversity in terms of something shared." ${ }^{55}$ Still, it is not clear how this "culture" can be distinguished from state-centric positivism. ${ }^{156}$ In our view, formalism provides far less protection against the undermining of law by power and politics than an interactional approach to law; in the absence of legal legitimacy, formal law cannot generate fidelity. ${ }^{157}$ What is more, Fuller's version of the rule of law requires rulers to be public and open in their lawmaking efforts, but formalism makes no such demands. ${ }^{158}$

The fifth insight we derive from Fuller is that it is useful to specify a particular legal understanding of legitimacy, at which we have already hinted at various points. Most international lawyers seem to assume that international law is legitimate, probably because formal sources of law are employed to create the law. Underlying this assumption is the belief that international law is created by state consent.

Thomas Franck is one of the few international legal theorists to tackle legitimacy headon, but he shares the dominant assumptions. His starting presumption is that state consent is the necessary but not sufficient condition for international legal legitimacy. Legitimacy is a key factor in explaining the influence of international law because legitimacy "accommodates a deeply held popular belief that for a system of rules to be fair, it must be firmly rooted in a framework of formal requirements about how rules are made, interpreted and applied." 159 Franck sets out four "objective factors" that, he claims, can assist in the identification of legitimate rules: determinacy (ability of a rule to convey a clear message), symbolic validation (ability of a rule to communicate authority through ritual or regularized practice), coherence (consistency of the rule and its application with other rules), and adherence (vertical nexus of a rule to a pyramid of secondary rules). ${ }^{160}$

\footnotetext{
${ }^{154}$ Koskenniemi, supra note 6 at 616.

${ }^{155}$ Martti Koskenniemi, "What is International Law for?" in Malcolm D. Evans, ed., International Law, $2^{\text {nd }}$ ed. (Oxford: Oxford University Press, 2006) 57 at 77.

156 Toope, supra note 146 at 111.

${ }^{157}$ Of course, our differences with Koskenniemi share much common ground with the main points of the debate between Hart and Fuller. See supra note 81.

${ }^{158}$ Fuller, Morality of Law, supra note 1 at 159.

${ }^{159}$ Thomas M. Franck, Fairness in International Law and Institutions (Oxford: Clarendon Press, 1995) at 7-8.

${ }^{160}$ For an overview, see ibid. at 30-46. Detailed discussions can be found in Thomas M. Franck, "Legitimacy in the International System" (1998) 82 American Journal of International Law 705 at 713 and, of course, in Franck, Legitimacy, supra note 59 at 25, 32, 35-36 and c. 11.
} 
We share some common ground with Franck, notably the focus on internal features of law as central to its power to promote commitment. The internal indicators of legitimacy we posit overlap in part with Franck's. However, the internal features of law play a strikingly different role in Franck's legitimacy theory than in our interactional conception. Franck's account remains explicitly positivist, both in its emphasis on state consent and in its reliance upon a rule of recognition to explain the source of international legal obligation. What is more, Franck's legitimacy goes only to the issue of compliance with law; law is created essentially through positivist hierarchies. We will explore the concept of legitimacy and its relationship to compliance in Chapter Three.

For now, it is enough to emphasise that legitimacy is related to compliance, ${ }^{161}$ but not through primarily rationalist explanations. When we say that law is "legitimate" we mean that it has the capacity to generate fidelity to the rule of law itself and not merely to specific rules. Legitimacy is created in three interlocked ways, each of which must be present to some substantial, though not necessarily complete, degree. The first and second sources of legitimacy relate to "social" requirements that underlie all forms of normativity; the third is distinctively "legal."

First, legal norms must be broadly congruent with underlying social norms. As we will explain in Chapter 2, if there are absolutely no shared understandings of the role of law, and of particular candidate norms, it will be difficult if not impossible to see the norms emerge as "law". Of course, it may be possible to use legal tools to try to foster a social consensus, but we suggest that this is harder and rarer than commonly thought. Second is the idea of participation. Influential norms will not emerge in the absence of processes that allow for the active participation of relevant social actors. The requirement of participation is inherent in the idea of communities of practice that we employ and that explains both the creation of shared social understandings and the importance of a shared practice of legality. "Active participation" must be understood in specific contexts. Although he does not use the term "legitimacy," Andrew Hurrell captures the variety of ways in which participation in international society can be conceived:

some acceptance of equality of status, of respect, and of consideration; some commitment to reciprocity and to the public justification of one's actions; some capacity for autonomous decision making on the basis of reasonable information; a degree of uncoerced willingness to participate; a situation in which the most disadvantaged perceive themselves as having some stake in the system; and some institutional processes by which the weak and disadvantaged are able to make their voice heard and to express claims about unjust treatment. ${ }^{162}$

When these two dimensions of social legitimacy are substantially present, lawmakers can turn their attention to the task of generating "legal legitimacy". Thirdly, for any norm to be legitimate as "law," Fuller's criteria of legality must be substantially met. When these criteria are met and reinforced through a practice of legality, they permit productive

\footnotetext{
${ }^{161}$ See infra Chapter 3.

${ }^{162}$ See Andrew Hurrell, "Global Inequality and International Institutions" in Thomas W. Pogge, ed., Global Justice (Oxford: Blackwell, 2001) 32 at 42.
} 
interaction between the lawgiver and the citizen. The lawgiver can expect that the citizen will understand and respect the law; the citizen can expect that the lawgiver will faithfully adhere to the law. That interaction is what makes this relationship "horizontal" and "reciprocal," and is the core of "legal" legitimacy.

This conception of legality, together with the two dimensions of social legitimacy, implies another legitimizing attribute of legal norms: they are built through continuous practice, a point that also resonates strongly with constructivist insights into the interplay between actors and norms. The idea of continuous practice will hardly be novel to international lawyers. It is central to the concept of customary law and also plays a significant role in the evolution of treaties. What is added through our account of legal legitimacy is the idea that a very particular kind of practice is required to make and sustain international legal norms: inclusive practice that adheres to the requirements of legality. As we will illustrate in subsequent chapters, this perspective reveals the real weakness of many customary or treaty rules. This weakness lies not in the absence of enforcement or other attributes of "hard" law, but in a legitimacy deficit resulting from limited participation and insufficient attention to the requirements of legality. At the same time, our framework provides concrete guidance for practice that would strengthen international law.

A final point is worth making: even powerful states cannot simply impose "rules". If the legal rule is not grounded in shared understandings and if the criteria of legality are only weakly or imperfectly met, the rule will not generate fidelity. The rule may be on the book, so to speak, but it will not be employed in the reasoning of states as to appropriate behaviour. The treaty on Trade Related Aspects of Intellectual Property Rights (TRIPS) is a classic example: despite clear rules matched with a compulsory dispute resolution procedure, the treaty has failed to stem the tide of pirating. [CHECK] Conversely, even powerful states cannot simply re-interpret existing rules to their liking. The same dynamics will restrain them. The concerted efforts of the George W. Bush Administration to expand the existing right of self defence to include a broad right of "preventive war" have failed. In the UN reform processes of 2005, the existing framework of self-defence was reaffirmed by global consensus. ${ }^{163}$ Arguing for the ability of interactional law to constrain power is not to deny that powerful states (and other actors) have a privileged place in international lawmaking. By virtue of their greater resources, they have a stronger capacity to influence communication than poor states. ${ }^{164}$

\section{Conclusion}

\footnotetext{
${ }^{163}$ See Jutta Brunnée \& Stephen J. Toope, “The Use of Force: International Law After Iraq" (2004) 53 International and Comparative Law Quarterly 785; and Chapter 3. See also Stephen Toope, "Powerful but Unpersuasive? The Role of the United States in the Evolution of Customary International Law" in Michael Byers \& Georg Nolte, eds., United States Hegemony and the Foundations of International Law (Cambridge: Cambridge University Press, 2003) 287.

${ }^{164}$ Joseph S. Nye, Jr., Soft Power: The Means to Success in World Politics (New York: Public Affairs, 2004). See also the discussion of power in Chapter 2.
} 
Is there any added value to law and to legal obligation? If so, how is this added value created? The interactional theory of law explains that it is obligation that constitutes law's value added, not form, and that a sense of obligation will only arise when states and other actors perceive lawmaking to be legitimate. The creation of legal legitimacy is best explained as comprising three elements, the first two being related to the emergence of social norms, the last being more precisely directed to the creation of law. First, states and other international actors must build up shared understandings of the appropriate role of normativity in society, and of specific candidate norms. Second, influential norms are generated through the active participation of all relevant social actors. Third, international actors must work to ensure that the specific criteria of legality are met and then reinforced through a continuing practice of legality. Our description of the hard work of international law underscores that law is not a product that is manufactured in centralized, hierarchical systems and merely distributed to social actors for consumption. Citizens in domestic systems, and states and other actors at the international level, are not consumers; they are active agents in the continuing enterprise of lawmaking. 